\author{
NICOLÒ FERRARI \\ THE UNIVERSITY OF MANCHESTER
}

\title{
NEW FINDINGS ON THE ORIGIN AND MAKING OF NAPOLI, BIBLIOTECA NAZIONALE, MS VI E 40*
}

\section{INTRODUCTION}

$\mathrm{T}$ he manuscript Napoli, Biblioteca Nazionale Vittorio Emanuele III, MS VI.E.40 (hereafter NapBN 40), discovered by Dragan Plamenac in 1925 , ${ }^{\mathrm{I}}$ contains a cycle of six anonymous L'homme armé Masses. The first five of these are based on consecutive portions of the L'homme armé tune copied in the tenor, while the sixth and final one is set to the entire melody. Verbal canons, one for each setting, rich in Virgilian allusions, ${ }^{2}$ prescribe how each fragment in the tenor should be performed in order to obtain the complete part. This manuscript is the only one transmitting the text and melody of L'homme armé in its entirety; furthermore, the combination

* I would like to express my thanks to the anonymous reviewers of this journal for their suggestions for revisions and improvements. Many thanks also to Thomas Schmidt, Katherine Lewis, Vincenzo Borghetti and Alexandros Hatzikiriakos for reading and commenting on various draft versions of this article, and to Caroline Gill for the help provided.

The identification of the coat of arms was first presented in a paper read at the Medieval and Renaissance Music Conference (MedRen), Edinburgh, 1-4 July 2020. At the same conference, another paper independently reported the same identification. Cf. John Ahern, 'The Naples L'homme armé Masses: A New Connection', MedRen 2020, 4 July 2020; Nicolò Ferrari, 'Crusading Propaganda and Fifteenth-Century L'homme armé Masses', MedRen 2020, 4 July 2020.

1 Dragan Plamenac, 'La chanson de L'homme armé et le MS VI.E.40 de la Bibliothèque Nationale de Naples', in: Annales de la Féderation archéologique et historique de Belgique. Congrès jubilaire sous les auspices des Ministeres des Sciences et Arts, des Affaires étrangeres et de la ville de Bruges, Bruges 1926, pp. 229-230.

2 Barbara Haggh, 'Letter from Barbara Helen Haggh', Journal of the American Musicological Society 40 (1987) no. 1, pp. 139-143 (with a translation and interpretation of the Naples texts by Steven M. Whiting). Michael Long offered a possible interpretation of the canons, though his hypothesis is invalidated by several aporias. Michael Long, 'Arma virumque cano. Echoes of a Golden Age', in: Antoine Busnoys: Method, Meaning, and Context in Late Medieval Music, ed. Paula Higgins, Oxford 1999, pp. 133-154. The criticalities of Long's contribution are discussed in: Maria Caraci, 'Johannes Ockeghem. Actes du XL Colloque international d'Études humanistes, edités par Philippe Vendrix, Paris, Klinksieck, 1998. Antoine Busnois, Method, Meaning and Context in Late Medieval Music, ed. Paula Higgins, Oxford, Clarendon Press, 1999', Philomusica on-line 1 (2001) no. 1. 
of anonymity with the tradition of works composed on this tune, the peculiarity of the structure of the settings, and the fact that they survive in such a beautiful and uniquely laid-out source helped to attract the attention of musicologists.

At the end of the manuscript, there is a dedicatory epigram and a hitherto unidentified coat of arms. The dedication states that the manuscript was intended as a gift to Beatrice of Aragon, queen of Hungary, and that a prince Charles (Charolus princeps) used to enjoy it. This, along with paleographical evidence, has been taken to indicate a Burgundian origin, since the Charolus of the dedication has been interpreted by Judith Cohen, author of a monograph on this manuscript based on her PhD dissertation, ${ }^{3}$ as Charles the Bold, the last Duke of Burgundy.

Cohen's monograph, while generally reliable, is more than half a century old and much in need of being updated, considering the scholarship published subsequently: while no definitive answer has been offered on who composed these masses, ${ }^{4}$ crucial research into the Burgundian cultural context has been published. 5 Already almost twenty years ago, Alejandro Planchart, in his valuable contribution to the early history of the L'homme armé tradition, pointed out the necessity of an updated study of this manuscript. ${ }^{6}$ In this contribution, I shall offer some new insights into this important source. I will propose a new identification of the coat of arms at the end of the manuscript, with some consideration of the cultural framework in which it was commissioned and then donated. Furthermore, I will offer in the appendix a new description of the manuscript, ${ }^{7}$ revealing some details of Cohen's original description to be inaccurate and incorporating various findings on this manuscript which have been published over the last few years. Taken together, these new insights contribute to a comprehensive new understanding of this manuscript.

Judith Cohen, The Six Anonymous L'homme armé Masses in Naples, MS VI E 40, Dallas 1968.

4 The hypotheses put forward considered Tinctoris, Caron, and Busnoys as possible authors; however, they all have serious methodological issues. Dragan Plamenac, 'Zur "L’homme armé"-Frage', Zeitschrift für Musikwissenschaft 11 (1929), pp. 376-383; Don Giller, 'The Naples L'Homme Armé Masses and Caron: A Study in Musical Relationship', Current Musicology 32 (1981), pp. 7-28; Richard Taruskin, 'Antoine Busnoys and the "L'Homme Armé" Tradition', Journal of the American Musicological Society 39 (1986) no. 2, pp. 255-293.

5 Laurenz Lütteken, 'Ritual und Krise. Die neapolitanischen "L'homme armé"-Zyklen und die Semantik der Cantus firmus-Messe', in: Musik als Text. Bericht über den Internationalen Kongreß der Gesellschaft für Musikforschung. Freiburg im Bresgau 1993, eds. Hermann Danuser and Tobias Plebuch, Kassel 1998, pp. 207-218; Vincenzo Borghetti, 'Music and the Representation of Princely Power in the Fifteenth and Sixteenth Century', Acta Musicologica 80 (2008) no. 2, pp. 179-214.

6 Alejandro Enrique Planchart, 'The Origins and Early History of L'homme armé, The Journal of Musicology 20 (2003) no. 3, p. 307; Alejandro Enrique Planchart, Guillaume Du Fay: The Life, The Works, vol. 2, Cambridge 2018, p. 915 and passim; Guillaume Du Fay, Missa L'homme armé, ed. Alejandro Enrique Planchart, Santa Barbara 2011 (= Guillaume Du Fay Opera Omnia 3/5).

7 I follow the model for the description of music manuscripts outlined in the essays collected in The Production and Reading of Music Sources: Mise-en-page in Manuscripts and Printed Books Containing Polyphonic Music, 1480-1530, eds. Thomas Schmidt and Christian Thomas Leitmeir, Turnhout 2018. 


\section{A NEW IDENTIFICATION OF THE COAT OF ARMS}

As mentioned, the last folio of the manuscript (f. 64v) presents a dedicatory epigram, below which appears a coat of arms with a devise, interpreted by Cohen as 'Que par dieu soit'. While the epigram has received considerable attention, due to its importance for the Burgundian origin of the manuscript and its dedication to Beatrice of Aragon, the coat of arms and its devise remain so far unidentified. Cohen's library research remained largely fruitless. ${ }^{8}$ The only previous contribution aimed at identifying the coat of arms came from Barbara Haggh, ${ }^{9}$ who suggested that it was the arms of the de Clercq family, and specifically of Charles de Clercq. Charles de Clercq (I477-I533) was a prominent courtier of the Habsburg-Burgundian court at the beginning of the sixteenth century; a member of the 'new nobility', he held important offices, such as president of the Chambre de Comptes of Lille, and controlleur général of the officers of the Kingdom of Naples for Charles $v^{10}{ }^{10} \mathrm{He}$ was also renowned as a bibliophile, and several manuscripts have been associated with him, including a music manuscript (BrusBR 215-6) which bears his arms as well as those of his wife, Anne Annoke. ${ }^{\text {II }}$

Haggh associated NapBN 40 with Charles de Clercq due to the resemblance of the coat of arms in BrusBR 215-6 and his connection to Naples. Two of the quarters of the coat of arms present in BrusBR 215-6 at $\mathrm{f}$. $2 \mathrm{r}$ represent the arms of Jean de Clercq, Charles's father, which 'have an undivided field of blue tincture with a gold fess and three silver mullets, two above the fess and one below. ${ }^{2}{ }^{2}$ The coat of arms in NapBN 40, meanwhile, is described by Haggh as having a blue field with a fess and three besants, two above and one below the fess. While she acknowledged that the devise present in NapBN 40 is not associated with Jean de Clercq, Haggh noted that the motto of de Clercq's wife, Anne Annoke, Solum deum conveyed a similar message to the devise present in NapBN $40 .{ }^{13}$

However, a close examination of the coat of arms in NapBN 40 reveals that this hypothesis is not tenable. The fess, even though oxidised, still presents some silver traces, and the three charges are not besants, but rather cinquefoils; moreover, within the fess, it is possible to recognise a red crescent. Finally, a close examination of the

8 J. Cohen, Six Anonymous L'homme armé Masses, p. 11. Cohen researched the coat of arms in Naples (Biblioteca Nazionale Vittorio Emanuele III), Venice (Biblioteca Nazionale Marciana), Budapest (Egyetemi Könyvtar) and Brussels (Koninklijke Bibliotheek van België - Bibliothèque royale de Belgique).

9 Barbara Haggh, 'Charles de Clerc, Seigneur de Bouvekercke, and Two Manuscripts: Brussels, Bibliothèque Royale de Belgique, MS 215-16, and Naples, Biblioteca Nazionale, MS VI E 40', in: The Burgundian-Habsburg Court Complex of Music Manuscripts (1500-1535) and the Workshop of Petrus Alamire, eds. Bruno Bouckaert and Eugeen Schreurs, Leuven 2003, pp. 185-202.

10 Hanno Wijsman, Luxury Bound. Illustrated Manuscript Production and Noble and Princely Book Ownership in the Burgundian Netherlands (1400-1550), Turnhout 2010, p. 495.

11 Brussels, Koninklijke Bibliotheek van België - Bibliothèque royale de Belgique, MS 215-216. B. Haggh, 'Charles de Clerc', p. 185.

12 Ibid., p. 200.

13 Ibid., p. 201. 
devise shows that the reading 'Que par dieu soit', proposed by Cohen, ${ }^{\mathrm{I4}}$ is erroneous, and it should instead be read as 'De par dieu soit' (Fig. I and 2).

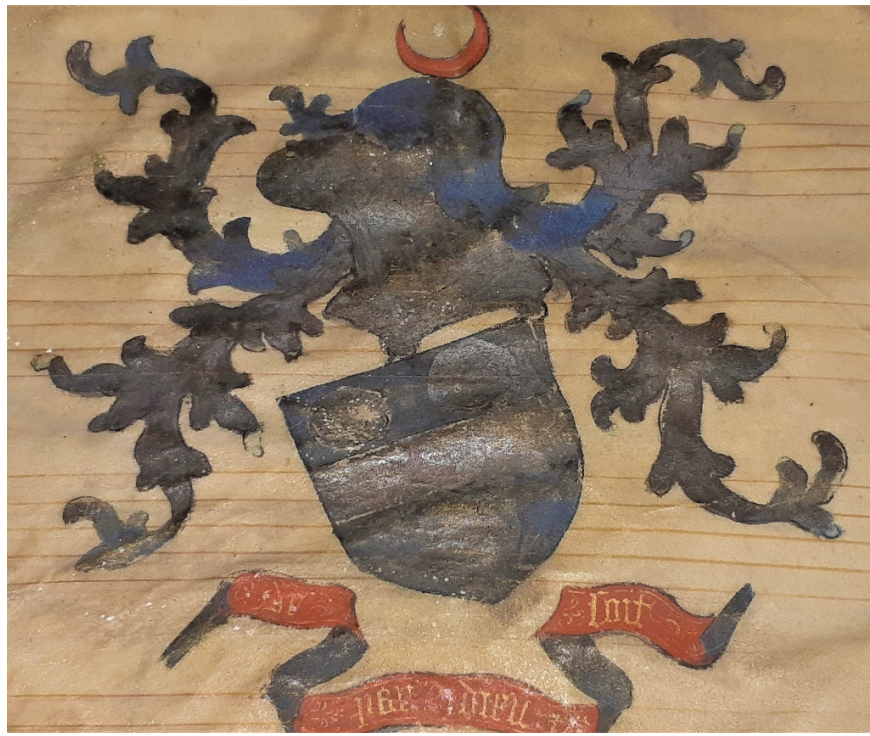

Fig. I. Coat of arms in Napoli, Biblioteca Nazionale, MS VI E 40, f. 64v, su concessione del Ministero della Cultura (C) Biblioteca Nazionale di Napoli

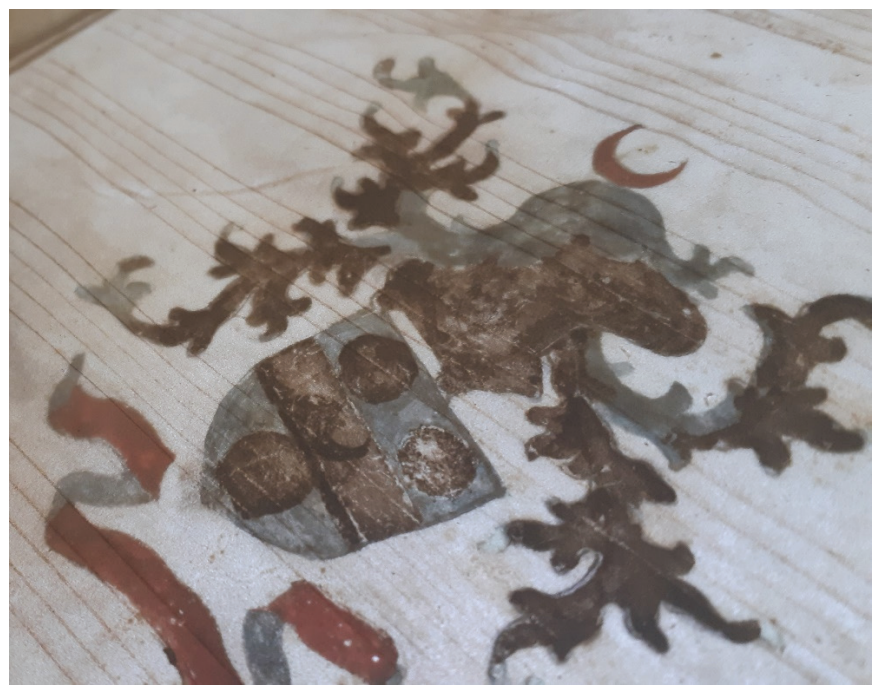

Fig. 2. Backlit version of the coat of arms, note the crescent in the middle of the fess, Biblioteca Nazionale, MS VI E 4O, f. 64v, su concessione del Ministero della Cultura (C) Biblioteca Nazionale di Napoli

14 J. Cohen, Six Anonymous L'homme armé Masses, p. 11. 
Indeed, a coat of arms like the one just described, along with the devise 'De par dieu soit', appears also in a 1476 incunabulum of Cristoforo Landino's Italian translation of Pliny the Elder's Historia Naturalis, which was published in Venice by Nicolaus Jenson and is today preserved at the British Library. ${ }^{15}$ This edition, printed in I024 copies, of which most are on paper but thirty-three are on parchment, was a venture sponsored by the Florentine bankers Filippo Strozzi and Giambattista Ridolfi. The copies were printed by the French engraver Jenson in an elegant humanist font with blank spaces left and no capital letters at the beginning of each book and chapter, so that each copy could be customised with illuminated capitals and decoration, often with the coat of arms of the buyer. ${ }^{16}$

The coat of arms appears twice in the copy of the British Library: at the beginning of the Libro primo as a decoration of the illuminated capital letter, and at the beginning of the Prohemio, where the coat is inserted in a bas-de-page decoration (Fig. 3a and $3 \mathrm{~b}$ ). The devise appears in the decoration of the border at the beginning of the Libro primo (twice) and four times in the borders of the Prohemio (see Appendix 5). It also appears at the end of the book in a handwritten battarde rubric below the colophon, along with the name 'Ianly' (Fig. 4). This family, whose name is variously spelled as de Janly, Janly, Ianly or de Ianley, was a Burgundian noble family which had a coat of arms described as: 'd'azur a une fasce d'argent, accompagnée de trois quinte-feûilles de mesme. ${ }^{17}$ This coat of arms can thus be identified beyond any reasonable doubt as the same one that appears in NapBN 40, corroborated by the identical devise.

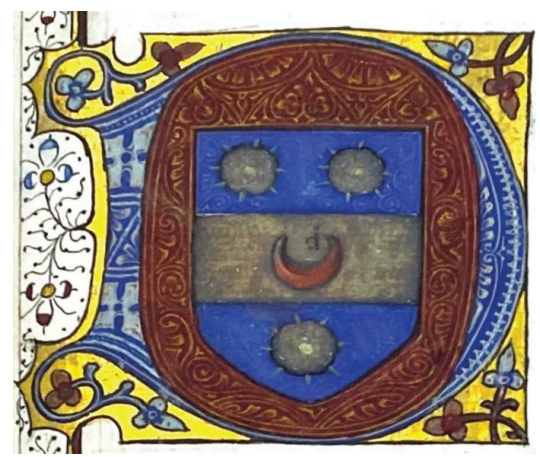

Fig 3 a. Coat of arms in the initial of the first page of Libro primo of Landino's translation of Pliny the Elder's Historia Naturalis, London, British Library, C.3.d.2. () British Library Board

15 London, British Library, C.3.d.2.

16 Eva Borsook, 'Filippo Strozzi and the Two Plinys: Civic Pride, Diplomacy, and Private Taste in Quattrocento Naples and Florence', I Tatti Studies in the Italian Renaissance 23 (2020) no. 1, p. 88; Florence Edler de Roover, 'New Facets on the Financing and Marketing of Early Printed Books', Bulletin of the Business Historical Society 27 (1953) no. 4, p. 228; Andrea Rizzi, 'Editing and Translating Pliny in Renaissance Italy: Agency, Collaboration and Visibility', Renaessanceforum - Journal of Renaissance Studies 14 (2018), pp. 125-127.

17 'Blue with a silver fess combined with three cinquefoils of the same colour'. Louvan Geliot, Le vraye et parfait science des armoires ou l'indice armorial de feu maistre, Paris 1664, p. 458. 


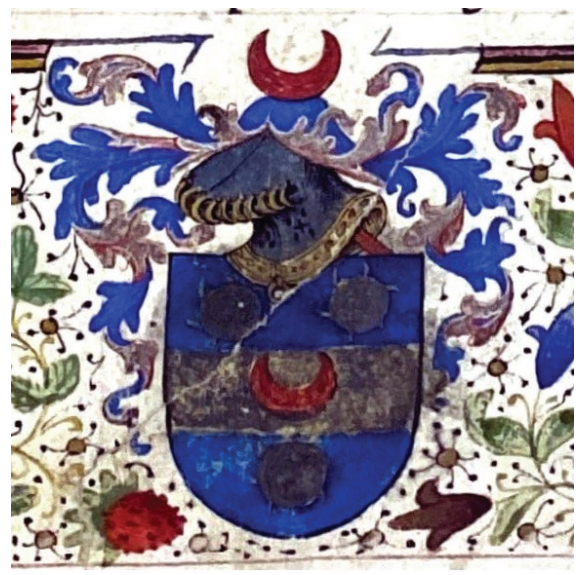

Fig. 3b. Coat of arms in London, British Library, C.3.d.2, appearing in the bas-de-page decoration of the first page of the Prohemio. (C) British Library Board

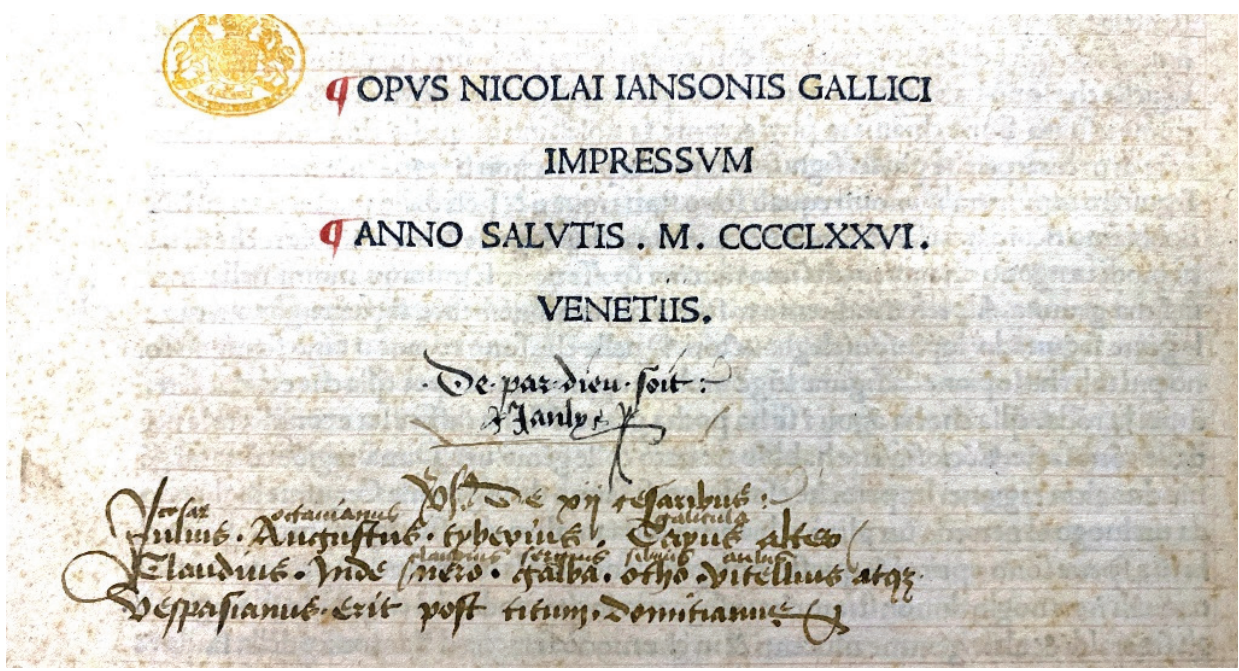

Fig. 4. Devise of the de Janly family below the colophon at the end of London, British Library, C.3.d.2. (C) British Library Board

Among the various members of the de Janly family, for reasons of chronology, three of them are possible candidates for an association with NapBN 40: Jean de Janly and his two sons. In an eighteenth-century list of Philip the Good's household, there is a reference to a Jean de Tenarre, lord of Janly, who acted as adviser and chamberlain, and was ennobled by Philip the Good in 1433 and since then known as 'Compte Jean Girard de Janly'. ${ }^{18}$ Philip the Good nominated him bailiff and

18 Louis-François-Joseph de La Barre, Mémoires pour servir à l'histoire de France et de Bourgogne, Paris 1729 , p. 220. 
grenetier of the salt-granary of Chalon-sur-Saône. ${ }^{19}$ In the ducal Comptes de l'argentier, Jean (d. after I474) is mentioned as ducal councillor and maître des requêtes de l'hôtel under Philip the Good and Charles the Bold, namely the person in charge of examining commoners' requests and petitions to the ducal household. In I467, he was also duke Philip's envoy to the King of Aragon and the Duke of Calabria, according to the Comptes and the memoirs of Philippe de Commynes, a nobleman and diplomat. ${ }^{20}$ His name appears in the list of the members of the Grand Conseil de Malines, also known as the Parliament of Mechelen, namely the highest court of law in the Burgundian Low Countries, founded and chaired by the duke Charles the Bold in $1473,{ }^{2 \mathrm{I}}$ he was probably promoted there in the first half of $\mathrm{I} 474$, as mentioned in the Comptes. ${ }^{22}$ Due to his role as maitre, it is possible to infer that he had a university education, a background also common to other ambassadors. ${ }^{23}$ In ${ }^{1426}$, Jean de Janly married Jeanne de Mâlain, daughter of Oudot of Mâlain; ${ }^{24}$ he had two sons and one daughter: Antoine, Philibert and Odette. Antoine (d. after 1519) was lord of Verchisy and Lays; ${ }^{25}$ he is variously mentioned in the Comptes as grand page of Charles the Bold in $1468,{ }^{26}$ valet servant in $1470,{ }^{27}$ and écuyer tranchant, namely the person responsible for cutting the meat and serving the duke, in I47I. ${ }^{28}$ Philibert

19 Jean Martin, 'L'église cathédrale Saint-Vincent de Chalon-sur-Saône. Pierre tombales \& documents historiques', in: Mémoires de la societé d'histoire et d'archeologie de Chalon-sur-Saône, Chalon-sur-Saône 1906, p. 23. The grenetier was the officer responsible for the grenier à sel, namely the place where all the salt produced in the region was stored so that the ducal monopoly was ensured. The grenetier was also in charge of the gabelle, the tax due for the purchase of salt. Malcolm G.A. Vale, Charles VII, BerkeleyLos Angeles 1974, p. 244.

20 Comptes de l'Argentier de Charles le Téméraire, duc de Bourgogne, eds. Anke Greve and Émilie Lebailly, vol. 1, Paris 2001, p. 446; Philippe de Commynes, The Historical Memoirs of Philip De Comines, London 1817, p. 120. A few years later, in 1470, Charles the Bold sent him to the fief of Hesdin, in Montreuil, to take care of some unmentioned ducal business. Comptes de l'Argentier de Charles le Téméraire, duc de Bourgogne, eds. Valérie Bessey, Véronique Flammang and Émilie Lebailly, vol. 3/1, Paris 2008, pp. 387-388.

21 Other sources report that he died in 1471; Charles Bigarne, 'Les capitanes du chateau de Beaune, études généalogiques', Société d'histoire, d'archéologie et de littérature de l'arrondissement de Beaune. Mémoires année 1886 (1887), p. 119.

22 Comptes de l'Argentier de Charles le Téméraire, duc de Bourgogne, eds. Valérie Bessey and Sébastien Hamel, vol. 4, Paris 2009, pp. 111-112.

23 Anne-Brigitte Spitzbarth, Ambassades et ambassadeurs de Philippe le Bon, troisième duc Valois de Bourgogne (1419-1467), Turnhout 2013, pp. 252-254. Spitzbarth mentions a Jean de Jauly as ambassador to the King of Aragon in 1467, proposing to identify him as Jean Joly, who led a mission regarding the boundaries between Burgundy and France in 1463; ibid., p. 99.

24 Lord of Lux and Demigny, ennobled by Philip the Good in 1433, then appointed as his counsellor in 1439; Henri Beaune and Jules D’Arbaumont, La noblesse aux états de Bourgogne de 1350 à 1789 , Dijon 1864, p. 230.

25 J. Martin 'L'église cathédrale', p. 13.

26 Comptes de l'Argentier de Charles le Téméraire, duc de Bourgogne, eds. Anke Greve and Émilie Lebailly, vol. 2, Paris 2002, p. 253.

27 Comptes de l'Argentier, vol. 3/1, p. 400.

28 Comptes de l'Argentier, vol. 4, p. 33; Louis Prosper Gachard, 'Analectes historiques, Cinquième série', Compte-rendu des séances de la commission royale d'histoire 9 (1857), p. 121. 
(d. c.I5I2) was protonotaire of the Holy See, dean of the cathedral of Chalon-sur-Saône in $1475,{ }^{29}$ and member of the Parliament of Burgundy in Beaune in $1474,{ }^{30}$ he was also famous for his singular erudition and his command of Hebrew. ${ }^{31}$ Given their roles in the government of the Burgundian domains, it is quite clear that we are dealing with members of a prominent family, well regarded by dukes Philip and Charles.

Both Jean and Antoine can be excluded, as their coat of arms is undifferentiated, i.e. not presenting a crescent within the fess, as they were the successive heads of the family; Antoine's coat of arms probably had a brisure, a mark of cadency, while his father was alive, but the eldest son's brisure is usually a lambel, while the croissant, the crescent, was usually reserved for younger sons..$^{32}$ Therefore, it is most likely that Philibert de Janly was the member of the family using the coat of arms with the crescent. Another piece of evidence pointing to Philibert is the presence of a handwritten rubric in the incunabulum at the end of the Prohemio reading: 'Prothonotaire de Rouray'. ${ }^{33}$ As mentioned, Philibert was renowned for his erudition, and it is not unlikely that he had an interest in a book such as the Pliny translation. This is corroborated also by his status as a courtier. The Burgundian court, as Hanno Wijsman notes, was a socially mobile environment: office holders were often granted a noble title for their service by the duke. Many of these new courtiers, such as the de Janly family, hailed from the French duchy of Burgundy and were appointed also to posts in the ducal domains in the Low Countries. Their educational background also generally differed from that of the high nobility, with most of the new courtiers having a university education. Their position was further strengthened through political marriages, especially in the generations subsequent to their original advancement, and their status was enhanced through arts patronage, such as the commissioning or - as in the case of the Jenson incunabulum - purchasing of lavishly illuminated manuscripts and books. There was a trend in book and manuscript ownership in Burgundy: the tastes of the duke were emulated by the high nobility, and they in turn were imitated by the new courtiers, who, due to their university education, also collected scholarly, humanistic books. ${ }^{34}$

The bibliophilia of the new courtiers regularly extended to books of polyphony; Jane Alden has shown how the Loire Valley chansonniers belonged to the milieu of

29 J. Martin, 'L'église cathédrale', p. 13.

30 Pierre Palliot, Le Parlament de Bourgongne, son origine, son etablissement, et son progrés, Dijon 1649, p. 17.

31 Ibid., p. 17; Pierre de Saint-Julien, De l'origine des Bourgongnons, et antiquité des estats de Bourgongne, Paris 1581, p. 327.

32 Jean-Baptiste Rietstap, Armorial Général: précédé d'un Dictionnaire des termes du blaison, Gouda 1884, vol. 1, p. xxiv.

33 Rouray was a small village in Chalon-sur-Saône diocese and the location of a maison de plaisance of the duke of Burgundy; Jean Joseph d'Expilly, Dictionnaire géographique, historique et politique des Gaules et de la France, vol. 6, Amsterdam 1770, p. 541.

34 H. Wijsman, Luxury Bound, pp. 481-483. 
the French noblesse de robe, secretaries and notaries ennobled for their service to the French crown and higher nobility. ${ }^{35}$ Alden notes that the new courtiers' efforts to emulate the higher nobility involved the commissioning and acquisition of works of arts as well as manuscripts, and this lay behind the majority of commissions of artworks in the fifteenth century. ${ }^{36}$ She also points out that the new courtiers sought musical competence, due to its association with the more established nobility. ${ }^{37}$ Chansonniers were not the only type of books containing music that was enjoyed by the new courtiers, as NapBN 40 shows. However, this is not the only manuscript containing Masses, and in particular L'homme armé Masses, commissioned by a member of the Burgundian nobility. An illustrious example can be traced in the so-called Chigi Codex, ${ }^{38}$ which was copied for Philippe Bouton (I4I8-I5I5), a member of the low nobility, courtier to Philip the Good, Charles the Bold, Maximilian, and Philip the Fair, and a cousin of Olivier de la Marche. ${ }^{39}$ While the Chigi Codex was produced slightly later than NapBN 40, between ${ }_{4} 498$ and I503, the similarities in their purpose and content are quite striking: both manuscripts were copied for members of the new nobility, courtiers of the duke of Burgundy, and, as I will discuss shortly, relatives of one of the most important crusading figures in Burgundy: Olivier de la Marche. Both manuscripts also contain several L'homme armé settings (five Masses on the tune by various composers are transmitted in the Chigi Codex).

While the Pliny text is a good example of humanistic ambitions, NapBN 40 represents Janly's alignment with one of the duke's foremost interests: crusading. Although Charles the Bold never really planned a crusading military campaign as his father had done, he fashioned himself throughout his life as a crusader and actively propagated a public profile as a virtuous prince and faithful Catholic, being well aware of the potency of crusading rhetoric for strengthening his political ambitions. ${ }^{40}$ Both Lütteken and Borghetti have clearly shown how this manuscript and its contents can be linked to the Burgundian late medieval crusading movement. ${ }^{4 \mathrm{I}}$ The fact that this manuscript corresponds to the interests of the duke is also demonstrated by the dedicatory epi-

35 Jane Alden, Songs, Scribes, and Society. The History and Reception of the Loire Valley Chansonniers, New York 2010, pp. 167-241. Joanna Frońska has also established that the chansonnier London, British Library, Royal Ms 20 A.xvi is linked to a French noble family belonging to the new courtiers. Joanna Frońska, 'London, British Library, Royal Ms 20 A. XVI', in: The Production and Reading of Music Sources: Mise-en-page in Manuscripts and Printed Books Containing Polyphonic Music, 1480-1530, eds. Thomas Schmidt and Christian Thomas Leitmeir, Turnhout 2018, pp. 263-268.

36 J. Alden, Songs, Scribes, and Society, pp. 168-169.

37 Ibid., p. 187.

38 Città del Vaticano, Biblioteca Apostolica Vaticana, MS Chigi C VIII 234.

39 Herbert Kellman, 'Introduction', in: Vatican City, Biblioteca Apostolica Vaticana, MS Chigi C VIII 234, New York 1987 (= Renaissance Music in Facsimile 22), p. vi.

40 Richard Walsh, 'Charles the Bold and the Crusade: Politics and Propaganda', Journal of Medieval History 3 (1977) no. 1, pp. 53-86.

41 L. Lütteken, 'Ritual und Krise'; V. Borghetti, 'Music and Representation'. 
gram, which reads at line fifteen: 'Charolus hoc princeps quondam gaudere solebat' ('Duke Charles used to take pleasure in this'). There is considerable evidence that Philibert, and the de Janly family more generally, shared this involvement with the crusades, an interest that was of pivotal importance at the Burgundian court. Odette, daughter of Jean de Janly and sister of Philibert, was the first wife of Olivier de la Marche, who married her $c .1455 .{ }^{42}$ Olivier de la Marche was a central figure of the Burgundian state under Philip the Good and Charles the Bold: he had a distinguished career as courtier and diplomat and, more importantly, played a crucial role in organising ceremonies at the court. Above all else, he was deeply involved in planning the Feast of the Pheasant, a spectacular event held in Lille on I7 February I454 set up by the duke to promote a crusade for the liberation of Constantinople. ${ }^{43}$ His connection to the Janlys goes further than his marriage to Odette: Antoine de Janly has also been linked to the de la Marche family, particularly with Olivier's son. ${ }^{44}$ Furthermore, the choice of a crescent as a brisure for Philibert's coat of arms might have been a way of showing his support for the dukes's crusading effort. The croissant was in fact a charge that was also added by nobles to show their or their ancestors' involvement in a crusade. ${ }^{45}$

\section{THE DEDICATION TO BEATRICE OF ARAGON}

Coming now to the dedication of this manuscript to Beatrice, the epigram at the beginning clearly states: 'Ad serenissimam Ungarie Reginam', also naming Beatrice in the first line. Despite that, Beatrice has been considered by Ronald Woodley as a mere intermediary, her husband King Matthias being the real recipient of this gift. ${ }^{46}$ According to Woodley, the dedication of the manuscript to Beatrice and not to Matthias was motivated by the delicate political situation between Burgundy and Hungary. Although the two realms were on friendly terms, an alliance was not possible at the time due to the political tensions with the Holy Roman Emperor. Woodley also assumed that the crusading allusions better suited Matthias, because of his military endeavours against the Ottomans. I would argue, however, that we should still consider Beatrice as the intended recipient of the manuscript. Recent scholarship has

42 Henri Stein, Olivier de la Marche. Historien, poète et diplomate Bourguignon, Paris 1888, p. 83; Marie-Thérèse Caron, Les voeux du Faisan, noblesse en fête, esprit de croisade. Le manuscrit Français 11594 de la Bibliothèque Nationale de France, Turnhout 2003, p. 291.

43 Alistair Millar, Olivier de la Marche and the Court of Burgundy, c. 1425-1502, The University of Edinburgh 1996 ( $\mathrm{PhD}$ dissertation).

44 Louis Michon, Inventaire-sommaire des archives départementales de Saône-et-Loire antérieures à 1790. 1 re partie. Archives civiles. Séries D-E, Macon 1877, p. 319.

45 Louis de Magny, La science du blazon, accompagnée d'un armorial général des familles nobles de l'Europe, Paris 1858 , p. 83.

46 Ronald Woodley, 'Tinctoris's Italian Translation of the Golden Fleece Statutes: A Text and a (Possible) Context', Early Music History 8 (1988), pp. 186-187. 
highlighted that a continuous alliance did exist between Burgundy and Hungary. ${ }^{47}$ Moreover, Beatrice's role could have been rather more active than what one might imagine. ${ }^{48}$ She was surely capable of understanding the allusions contained in the manuscript, since she received the same education as boys, as was customary for the House of Aragon, so she was familiar with Virgil, having received manuscripts of his works as a gift from her father; ${ }^{49}$ she was described as a strong woman and in I477 accompanied Matthias on active campaign against the Turks. ${ }^{\circ \circ}$ She had a good knowledge of music, having been tutored by one of the most important music theorists of the time, Johannes Tinctoris, who dedicated three of his treatises to her and also compiled the Mellon Chansonnier as a wedding gift for her, which contains the chanson Il sera par vous-L'homme armé. Therefore, she might have been already familiar with the tune. Moreover, she came from a family with a strong crusading tradition, and research has re-evaluated the involvement of women in the crusading movement. Women were invested with the role of preserving the family tradition and often were the repository of its crusading past. They were, as Nicholas Paul argues, 'strong, although often invisible links in the chain of family memory'. ${ }^{\text {II }}$

Since the dedication is in a hand different from that of the main body of the manuscript and added on a blank page, it is not possible to establish if the manuscript was commissioned by de Janly specifically to be donated to Beatrice or if it was given to her at a later date. It is unlikely that Philibert de Janly knew Beatrice personally, as testified in the dedication, where it is said that the manuscript is a 'munus ab ignoto', a gift from one unknown; it is possible, however, that Jean de Janly might have been known to the Neapolitan Aragonese household, due to his role as Philip the Good's envoy to the King of Aragon. As for the motives, Marcel Mauss, in his seminal book Essai sur le don, ${ }^{52}$ highlighted that gifts were part of a system of exchange implying some

47 Attila Bárány, 'King Matthias and the Western European Powers', in: Matthias Rex 1458-1490- Hungary at the Dawn of the Renaissance, ed. István Draskóczy, Budapest 2013.

48 On the ways in which women's various reading interests intertwined with their political roles, see Katherine J. Lewis, 'Women and Power', in: Historians on John Gower, eds. Stephen H. Rigby and Echard Siân, Cambridge 2019, pp. 323-350.

49 Péter Farbaky, 'Patrons and Patterns: The Connection Between the Aragon Dynasty of Naples and the Hungarian Court of Matthias Corvinus', Radovi Instituta za povijest umjetnosti 41 (2017), p. 24.

50 Valery Rees, "A Woman of Valour": Towards a Reappraisal of the Presence of Beatrix of Aragon in the Hungarian Court', in: Matthias Rex 1458-1490 - Hungary at the Dawn of the Renaissance, ed. Istvan Draskóczy, Budapest 2013, p. 5.

51 Nicholas L. Paul, To Follow in Their Footsteps. The Crusades and Family Memory in the High Middle Ages, Ithaca 2012, p. 16.

52 Marcel Mauss, The Gift. The Form and Reason for Exchange in Archaic Societies, London 2002. The importance of musical gifts has been extensively researched in Tim Shephard, 'Constructing Identities in a Music Manuscript: The Medici Codex as a Giff', Renaissance Quarterly 63 (2010) no. 1, pp. 84-127; Rob C. Wegman, 'Musical Offerings in the Renaissance', Early Music 33 (2005) no. 3, pp. 425-437; Giovanni Zanovello, "You Will Take This Sacred Book": The Musical Strambotto as a Learned Gift', Journal of the Royal Musical Association 141 (2016) no. 1, pp. 1-26. 
sort of reciprocation, while Natalie Zemon Davis suggests that books were specifically donated for social purposes going beyond the range of strict reciprocity. 53 It may well be that Philibert's intent was to establish a relationship with Beatrice in order to enhance his status as a noble. As Thomas Schmidt argues, 'there is a "public relations" value of being associated with a person of high rank or social status, with the possible benefit of achieving a higher standing in one's own professional context or in society at large'. ${ }^{4}$

Manuscripts participated in what Brigitte Buettner defines as 'asymmetric relationships', being almost exclusively presented as gifts from those of lower rank to members of the higher nobility. 55 Buettner investigates the early fifteenth-century ceremony of the étrennes, the ritual exchange of gifts on New Year's Day at the Valois court. These gifts (also called étrennes) were used among nobles to strengthen their position and their social connections..$^{56}$ Manuscripts rarely featured as presents among nobles of the same rank, being often considered simply not enough; established nobles preferred jewels, gold and other decorative art, while manuscripts were presented as gifts to rulers and aristocrats by new courtiers. ${ }^{57} \mathrm{Wijsman}$ notes how, from 1445 on, Duke Philip the Good received manuscripts mostly from new courtiers. ${ }^{58}$ While there are instances of the higher nobility, such as Lodewijk van Gruuthuse and Louis de Luxembourg, giving manuscripts as gifts, more often this choice of gifts was still upwards, namely from lower nobles to higher ones, ${ }^{59}$ and generally manuscripts were the gift of choice of new courtiers. ${ }^{60}$

It is not known if Beatrice received the manuscript while she was still in Naples or in Hungary. We do know that when she moved to Hungary, she brought with her several manuscripts from Naples to establish her personal library in Buda, which is estimated to have included between 50 and 100 manuscripts, ${ }^{6 \mathrm{I}}$ and she took away numerous manuscripts in $150 \mathrm{I}$ when she decided to return to Italy as a widow. ${ }^{62}$

53 Natalie Zemon Davis, 'Beyond the Markets: Books as Gifts in Sixteenth-Century France: The Prothero Lecture', Transactions of the Royal Historical Society 33 (1983), p. 87.

54 Thomas Schmidt, 'Dedicating Music Manuscripts: On Function and Form of Paratexts in Fifteenthand Sixteenth-Century Sources', in: 'Cui dono lepidum novum libellum?'. Dedicating Latin Works and Motets in the Sixteenth Century, ed. Ignace Bossuyt et al., Leuven 2008, p. 83.

55 Brigitte Buettner, 'Past Presents: New Year's Gifts at the Valois Courts, ca. 1400', The Art Bulletin 83 (2001) no. 4, p. 604.

56 Ibid., p. 600.

57 Ibid., pp. 604-609. On the central, and often neglected, role of applied arts, see Marina Belozerskaya, Rethinking the Renaissance. Burgundian Arts across Europe, Cambridge 2002.

58 H. Wijsman, Luxury Bound, p. 246.

59 Lodewijk van Gruuthuse presented a manuscript to Charles viII of France and Edward IV of England, and Louis de Luxembourg probably gave a manuscript to the duke of Savoy.

60 Ibid., pp. 539-545.

61 Csaba Csapodi, 'La biblioteca di Beatrice d'Aragona, moglie di Mattia Corvino', in: Italia ed Ungheria: dieci secoli di rapporti letterari, ed. Mátyás Horányi, Budapest 1967, pp. 113-133.

62 Ernesto Milano, 'I codici corviniani conservati nelle biblioteche italiane', in: Nel segno del corvo. Libri e miniature della biblioteca di Mattia Corvino, Modena 2002, p. 68. 
After her return, Beatrice retired to Castello Aragonese on the island of Ischia in the bay of Naples. It is likely that after her death the manuscript went to the library of the royal chapel at the church of Santa Croce di Palazzo in Naples. This church was part of the homonymous Franciscan convent, founded in 1338 by Queen Sancia of Majorca, which was made a royal chapel by King Alfonso of Aragon in I443; its library passed under the control of the Neapolitan Ministry of the Interior in I815, then to the Real Biblioteca Borbonica, which changed its name to Biblioteca Nazionale in $1860 .{ }^{63}$ The manuscript appears in the library's nineteenth-century topographic catalogue as 'Liber Choralis, notis musicis ornatus, fol: membr:' ${ }^{64} \mathrm{~A}$ rather unremarkable annotation for an extraordinary manuscript.

\section{CONCLUSION}

In light of the new findings presented here, it is possible to reassess the historical significance of NapBN 40. The involvement of Charles the Bold in the making of the manuscript becomes much less relevant, and it is likely that Philibert de Janly commissioned it as an object that would testify his support for the ducal crusading effort and at the same time enhance his status at the court. This also provides evidence of the patronage and ownership of polyphonic music manuscripts among Burgundian new courtiers, and their use as objects to be donated as gifts from lower nobles to those of higher standing. Most of all, this manuscript also attests to the fact that the relevance of music in the Burgundian crusading rhetoric was not limited to the Order of the Golden Fleece, but probably involved social and cultural life at all levels.

The insights presented here also relate to questions about women's ownership and use of books, as well as their participation in the culture of crusading. Although, as we have seen, it is not clear when de Janly decided to donate the manuscript to Beatrice of Aragon, there is no reason to doubt that she - rather than her husband Matthias - was the intended recipient of the gift. Beatrice was a woman of profound culture, from a family with a long crusading tradition that ruled a realm in continuous struggle with the Turks. While the motives behind this gift may not be entirely clear, crusading culture clearly played an important role here too, and Philibert's gift appealed to the status of Beatrice and to her involvement in the crusading movement in the hope of achieving a higher social status. It is evident here how NapBN 40 can be considered a unique piece of evidence of the cultural complexity surrounding manuscripts in the late Middle Ages. Its unparalleled features, as well as the network of protagonists of later crusading history revealed by its commissioning and donation, show how much work still lies ahead of us before we fully understand this extraordinary object.

63 Ibid., p. 78.

64 The signature VI E 40 is crossed out in pencil, and added below is a new location: Vetrina XI. 
APPENDIX I

CODICOLOGICAL DESCRIPTION ${ }^{65}$

NapBN 40 is made up of 64 parchment folios measuring on average $430-445 \times$ $315-320 \mathrm{~mm} .{ }^{66}$ The external binding structure, which appears to be original, comprises, as was customary, two leather-covered pasteboard boards displaying blind tooling and metal furnishings: on the front there are four bosses, one centrepiece and three cornerpieces, with the lower-right cornerpiece missing, while on the back there are five bosses, one centrepiece and four cornerpieces. There are two paper pastedowns: the front pastedown bears the signature of the manuscripts written in ink and in pencil, which also appears on a library label; on the back pastedown, there is an inscription, in an eighteenth-century hand, commenting on the dedicatory epigram on f. $64 \mathrm{v} \cdot{ }^{67}$ The manuscript has no original foliation or index, and it is foliated in a modern hand in pencil in the upper right corner of the rectos and in the upper left corner of the versos.

There are ten gatherings, all originally quaternions (with one exception), with several folios missing. The gatherings follow, as is usual for late medieval manuscripts, the two main assembling rules, namely Gregory's Rule, and the rule of having the flesh side on the outside of a gathering. Only two gatherings are complete (VI and Ix), four have one folio missing (I, II, III, VIII), while a bifolium is missing in four of them (IV, V, VII, $\mathrm{x})$. Therefore, the gathering structure is as follows: $\mathrm{I}^{8-\mathrm{I}}, \mathrm{II}^{8-\mathrm{I}}, \mathrm{III}^{8-\mathrm{I}}, \mathrm{IV}^{8-2}, \mathrm{~V}^{8-2}$, $\mathrm{VI}^{8}, \mathrm{VII}^{8-2}, \mathrm{VIII}^{8-\mathrm{I}}, \mathrm{IX}^{8}, \mathrm{X}^{4-2}$. The third gathering, described here as a quaternion with a single folio missing, is not lacking any text. The assumption of an original ternion with an added singleton can be ruled out by the presence of a stub, clearly visible between $\mathrm{f}$. I8v and f. I9r; in addition, the manuscript as a whole is composed of quaternions, the standard codicological unit for coeval Franco-Flemish music manuscripts. In this case, since the text here is complete, it is probable that the folio was removed before, or perhaps during, the process of copying. In gathering vIII, another stub is

65 The following remarks draw on an autopsy of the manuscript conducted on 6 March 2020.

66 Folios range from $445 \times 315 \mathrm{~mm}$ (f. 2), to $430 \times 320 \mathrm{~mm}$ (f. 64). A notable exception is f. 53, which measures $440 \times 250 \mathrm{~mm}$.

67 The inscription reads: 'Carlo di Francia primo di questo nome Re di Napoli e di Sicilia. | Era figlio del Re Luigi viII. sopranominato il Lione e fratello di S. Luigi. | Questi nacque nel mese di Marzo 1220, e sposò Beatrice ereditiera e | quarta figlia di Raimondo Berenger Conte di Provenza. A questa Regi|na fu il presente manoscritto dedicato. Il titolo Ad serenissimam Unga|rie Reginam è stato scritto dopo, prendendosi una svista, mentre | Maria moglie di Carlo II fu Regina di Ungheria, a quale stato | poi successe Carlo Martello loro figlio.'

(Charles of France, first of his name, king of Naples and Sicily, was son of king Louis viII, known as the Lion and brother of St Louis. He was born in March 1220, and married Beatrice, heir and fourth daughter of Ramon Berenguer, count of Provence. To this queen this manuscript was dedicated. The title Ad serenissimam Ungarie Regina was written later, erroneously, since Mary, wife of Charles II, was Queen of Hungary, succeeded by Charles Martel, their son). 
visible, between f. $52 \mathrm{~V}$ and f. $53 \mathrm{r}$, but here some text is missing, so the deduction of an original complete quaternion is quite straightforward.

All the missing folios are consistently linked to the excision of the first page of each Mass, which was probably lavishly illuminated. Therefore, the missing single folia contain, besides the missing discantus and tenor of the first Kyrie, often the two contratenores parts of the second and third Agnus as well. Sometimes the conjugate leaf is also missing, its removal resulting in the loss of parts from other movements of the Mass, such as the Gloria in Missa v, or the Credo and the Sanctus in Missa III. The final gathering is lacking the contratenor parts of the first Agnus and the whole of the second and third Agnus; that an entire bifolium is missing here is conjectured on the basis of all the other Agnus sections from the first five Masses having been copied on two bifolia. It is not possible to discern if the removal of the bifolia was intentional or the result of the excision of the first page of each Mass, with the remaining single leaf, now loose due to the loss of its conjugate leaf, lost at a later date. However, it seems unlikely that the folia other than that of the first page of each setting had any illumination, therefore their loss was probably the accidental result of the removal of their conjoints.

\section{PAGE PREPARATION}

The text block measures on average between 355 and $400 \mathrm{~mm}$ in height and between 235 and $260 \mathrm{~mm}$ in width. ${ }^{68}$ Single vertical boundary lines were drawn in lead point in the left and right margins of the text block and are occasionally visible on some folios. No pricking for the boundary lines is visible, possibly due to trimming. The brown-ink staves were drawn freehand with a single rastrum measuring $15 \mathrm{~mm}$; the spacing between the staves is irregular, measuring on average between I8 and $20 \mathrm{~mm}$, with notable variations. There are no horizontal lines other than the music staves; often the staves are not perfectly parallel, and little endeavour was made to contain them between the boundary lines. Some notable exceptions where a stave is considerably extended to accommodate the music can be observed on ff. 8r, 37v, $45 \mathrm{v}, 50 \mathrm{v}$, and 6or.

The pages are regularly ruled with $\mathrm{I} 2$ staves each, with the exception of ff. $55 \mathrm{r}, 55 \mathrm{v}$, $56 \mathrm{r}, 56 \mathrm{v}, 57 \mathrm{v}, 6 \mathrm{Ir}, 6 \mathrm{IV}, 62 \mathrm{r}, 62 \mathrm{v}$, which contain I3 staves. Only in three cases does the thirteenth stave contain text, namely the canon rubric (ff. $55 \mathrm{v}$ and $6 \mathrm{Iv}$ ), and a portion of music (f. 62r); the only case in which an extra stave was effectively necessary is for the copying of music in f. 62r; therefore, it seems likely that the extra staves were originally there before the copying started. It is possible that some of the staves of

68 The measuring has been done on the following cross-section of folios: f. $11 \mathrm{v}, 380 \times 240 \mathrm{~mm}$; f. $15 \mathrm{r}, 360$ $\times 245 \mathrm{~mm}$; f. $22 \mathrm{r}, 365 \times 245 \mathrm{~mm}$; f. $27 \mathrm{v}, 360 \times 240 \mathrm{~mm}$; f. $38 \mathrm{r}, 355 \times 250 \mathrm{~mm}$; f. $50 \mathrm{r}, 360 \times 240 \mathrm{~mm}$; f. 53 r, $355 \times 235 \mathrm{~mm}$; f. $55 \mathrm{v}, 400 \times 260 \mathrm{~mm}$; f. $62 \mathrm{r}, 370 \times 260 \mathrm{~mm}$. 
the missing first page of the six settings were indented, in order to accommodate an illuminated initial, or that the total number of staves of that page was less than $\mathrm{I} 2$, in order to reserve some space for other decorations.

The layout is typical of cantus collateralis, with the discantus and tenor on the left page of the opening, and the two contratenores on the right. The tenor has also a resolutio, probably added at a later stage but on the pre-ruled staves, in lighter ink, which does not seem to occupy a fixed space on the opening: usually it is placed underneath the tenor, but occasionally it is copied between the discantus and the tenor, or even across the opening on the facing recto page. Each voice naturally extends over a different number of staves: the tenor occupies just one stave consistently for the first five Masses, and three in the last one, where the melody of L'homme armé is copied in its entirety. Similarly, its resolutio - present exclusively in the first five settings - fills one or two staves. ${ }^{69}$ The discantus takes up between two and nine staves; ${ }^{70}$ the first contratenor (altus) between two and eight; $7^{71}$ the second contratenor (bassus) between two and six. ${ }^{72}$ In two instances, the music is copied on a single page layout, leaving the right page of the opening blank; this happens in the second setting at the end of two movements: in the Gloria - Cum Sancto Spiritu section - at f. I3v, with the voices copied from top to bottom as discantus, contratenor altus, contratenor bassus, tenor, resolutio, occupying respectively 3, 3, 2, I, I staves; and at the end of the Credo - Et unam sanctam - at f. I6v, with the voices copied as discantus, contratenor altus, contratenor bassus, resolutio and tenor, with 3, 2, 3, I, I filled staves. There does not seem to be a particular reason for the single page layout. For example, at ff. $4 \mathrm{IV}^{-} 42 \mathrm{r}$, namely the end of the Sanctus of the fourth Mass, the voices are copied on more or less the same number of staves, with the exception of the tenor, which is marked tacet, but they extend here over the entire opening. Another case is the end of the Gloria - here too the Cum Sancto Spiritu section - of the sixth Mass, at ff. $57 v^{-5} 58$, where all the voices occupy three staves each and could be easily accommodated on a single page; however, the scribe opted to use the entire opening.

An interesting feature of the mise-en-page is the unique layout of the tenor, which is articulated in two ways: the initial letter of the voice (see below on decoration), and its regular separation from the other voices. In fact, the tenor is always clearly

69 Number of staves occupied for each opening: Mass I, 1 stave (5 times), 2(4); Mass II, 1(11); Mass III, 1(9), 2(1); Mass Iv, 1(4), 2(8); Mass v, 1(8), 2(1).

70 Mass I, 4(2), 5(1), 6(2), 7(2), 8(2); Mass II, 3(3), 5(4), 6(1), 7(4); Mass III, 2(1), 5(1), 6(5), 8(1), 9(2); Mass Iv, 3(3), 6(8), 7(1); Mass v, 3(1), 4(2), 6(3), 8(2), 9(1); Mass vi, 3(4), 5(1), 6(2), 7(3), 8(1).

71 Mass I, 3(1), 4(1), 5(1), 6(4), 7(2); Mass II, 2(1), 3(1), 4(2), 5(4), 6(4); Mass III, 2(1), 5(6), 6(2), 7(1); Mass Iv, 3(3), 5(6), 6(1), 7(2); Mass v, 4(2), 5(1), 6(4), 8(2); Mass vi, 3(3), 4(2), 5(2), 6(3), 7(1).

72 Mass I, 3(2), 4(1), 5(4), 6(2); Mass II, 2(2), 3(1), 4(2), 5(5), 6(2); Mass III, 2(3), 4(4), 5(3); Mass IV, 2(1), 3(2), 5(9); Mass v, 3(3), 4(1), 5(3), 6(2); Mass vi, 3(5), 5(3), 6(3). 
separated from the other voices by at least one stave; ${ }^{73}$ as Vincenzo Borghetti notes, these features highlight the central role of this voice and its symbolic pre-eminence in the organisation of the manuscript, characterised by a strict relationship between the texts and their material support. ${ }^{74}$

\section{COPYING OF TEXT AND MUSIC}

The music is in void mensural notation, written in black ink, with a unique use of red ink to indicate sections in which the tenor is silent. ${ }^{75}$ The calligraphic standard of the music script is quite high; often the spacing is larger when breves and semibreves are present, and sometimes groups of notes are spaced according to the mensuration, making it clear which groups of notes constitute a tempus. Generally, the music is densely notated, with staves often left empty on the page.

The music was probably copied in two different campaigns: one for the main text, and the other one for the tenor resolutiones. For the main text, two different hands are present. The first (A) copied the music for the discantus and the two contratenores on ff. Ir-3IV, f. 33v, and ff. $45 \mathrm{v}-63 \mathrm{v}$. This is, as proposed by Klaas van der Heide, the same hand that copied the first four gatherings of the manuscript BrusBR $5557 .{ }^{76}$ Van der Heide also suggested identifying the copyist as Gauthier Vrankenzonne, a singer in the chapel of Charles the Bold, who was compensated for copying two

73 Sometimes the resolutiones are copied in the stave left empty between a voice and the Tenor; but it is clear that they were copied in a later campaign, by another copyist, who did not take into account the peculiarity of the mise-en-page of the manuscript. I do not agree with van der Heide, who claims the layout clearly shows that the insertion of the resolutiones was included in the original organisation of the manuscript. Klaas van der Heide, 'New Claims for a Burgundian Origin of the L'homme armé Tradition, and a Different View on the Relative Positions of the Earlier Masses in the Tradition', Tijdschrift van de Koninklijke Vereniging voor Nederlandse Muziekgeschiedenis 55 (2005) no. 1, p. 26. On the contrary, the resolutiones fill empty staves and do not seem to have a reserved space on the page: they can appear between the discantus and the tenor (as in f. 4v, f. 28v), after the tenor, as in the majority of cases, or on the right page of the opening along with the contratenores, as in $\mathrm{f}$. 32r.

74 V. Borghetti, 'Music and Representation', p. 206.

75 While the text is consistently written in black ink throughout, red ink is used also for clefs, mensuration signs, custodes and accidentals. Reduced-voice sections are notated in red also in the Eton Choirbook, cf. The Eton Choirbook. Facsimile and Introductory Study, ed. Magnus Williamson, Oxford 2010, pp. 27-28. A reverse approach is taken both in MS. Oxford; Bodleian Library, Selden B 26, and in Wolfenbüttel A, where the cantus firmus is notated in red; J. Cohen, Six Anonymous L'homme armé Masses, p. 13; Thomas Schmidt, 'Making Polyphonic Books in the Late Fifteenth and Early Sixteenth Centuries', in: The Production and Reading of Music Sources: Mise-en-page in Manuscripts and Printed Books Containing Polyphonic Music, 1480-1530, eds. Thomas Schmidt and Christian Thomas Leitmeir, Turnhout 2018, p. 59.

76 Brussels, Koninklijke Bibliotheek van België - Bibliothèque royale de Belgique, MS 5557. This hand has been identified as A by Sylvia W. Kenney; Rob C. Wegman, 'New Data Concerning the Origins and Chronology of Brussels, Koninklijke Bibliotheek, Manuscript 5557', Tijdschrift van de Vereniging voor Nederlandse Muziekgeschiedenis 36 (1986), p. 20. 
books of music, which might be BrusBR 5557 and NapBN 40. ${ }^{77}$ However, it has to be noted that this identification is a mere hypothesis not supported by any evidence; van der Heide based his theory on an entry of the Comptes de l'Argentier dated October 1469 (and not I470, as he reports), ${ }^{78}$ in which Vrankenzonne is paid for copying two large books of music. Also, as Wegman convincingly has shown, it is most likely that BrusBR 5557 was copied in 1468 or shortly before near Bruges, ${ }^{79}$ whereas Vrankenzonne, according to the Comptes, was based in The Hague. The second hand copied the tenor throughout the manuscript, as well as the other voices in f. Ir (limited to the Christe section), ff. Iv-2r, ff. Ior-IIr, ff. 22r-23r, ff. 32r-33r, f. $35 \mathrm{r}$ (limited to the two-stave section Domine deus of the second contratenor) and ff. $44 \mathrm{r}^{-} 45 \mathrm{r}$. The two hands can be distinguished from several features: the noteheads are of a more rhomboid shape in A, and more rounded in B, with A often drawing the stems as a separate stroke. The C-clef in A is squared, with no inclination of the compartments, which are united on the right side too, while $\mathrm{B}$ draws them with a descending oblique inclination and does not unite them on the right. Accidentals too are different between the two scribes, with A preferring the sign $\emptyset$, and $B \#$. The placement of puncta additionis, as noted by John Milsom, also shows that A tends to place them below the stave line, while B prefers to notate them above the stave line. ${ }^{80}$ The virgula in the mensuration signs indicating diminution is shorter and with a more pronounced inclination, almost horizontal, in A, while it is less inclined in B, who also tends to draw the sign of tempus imperfectum diminutum in one single stroke. Often, the C-clef typical of B appears at the beginning of a new section after the double line, when copied consecutively without a stave break. With the exception of the intervention at ff. Ir and 35r, B copied the entire first movement of the second, third, fourth and fifth settings. Overall, it seems that B is a more musically accomplished scribe than $\mathrm{A}$, and may be considered as the main scribe of the manuscript, not so much for the quantity of music copied, but rather in terms of priority: $\mathrm{B}$ takes care of the beginning of the central masses, intervening also here and there (as in $\mathrm{f}$. Ir and f. 35r), leaving the rest to the largely less competent A.

It is possible that $\mathrm{B}$ planned the entire manuscript before passing it to A. Each setting takes up between ten and thirteen openings, with movements consistently occupying between two and three openings (see below). In some instances, it is hard

77 K. van der Heide, 'New Claims', pp. 27-31. Unfortunately, van der Heide does not differentiate between the two hands, and suggests that the entire music was copied by a single scribe.

78 Comptes de l'Argentier, vol. 2, p. 280.

79 R. Wegman, 'New Data', pp. 15-16.

80 John Milsom, 'Dots before the Eyes: Regional Preferences for the Placement of Dots of Addition', Tijdschrift van de Koninklijke Vereniging voor Nederlandse Muziekgeschiedenis 67 (2017) no. 1/2, p. 207. Indeed, through the analysis of the placement of the dots of addition, Milsom too suggests that NapBN 40 was copied by two different scribes, though he does not mention that B also took care of the copying of the tenores. 
to understand the rationale behind the use of an entire opening for short sections that could have easily fitted in the previous opening (as in the case of the Tu solus section of the Gloria of the fourth Mass at ff. 35v-36r), and this might be explained by the pre-allocation of space for each setting before it was copied.

It should also be noted that the corrections appearing throughout the manuscript are exclusively found in sections copied by A; while the corrections are not extensive enough to establish the hand of the corrector, it is nevertheless interesting to note that some kind of review was carried out on the copied text. Actually, it seems plausible that $\mathrm{B}$ might be identified as the reviewer and corrector: ${ }^{8 \mathrm{I}}$ his role as the planner of the manuscript may also imply a supervisory role in relation to A's work as well. Corrections vary from interpolations of missing notes, accidentals, or words to various kinds of deletion, such as unnecessary stems; in a few instances, the particular use of red ink caused some confusion, resulting in sections copied in the wrong colour being traced over.

In the second campaign, as mentioned above, the resolutiones were added, probably here too by two different hands, the main one taking care of all but the ones in ff. $32 \mathrm{r}-33 \mathrm{v}$ and $\mathrm{f} .34 \mathrm{v}$, which are written in another hand.

The verbal text is in a fairly elegant batarde, and the entire main corpus seems to have been copied by the same person. Here too, van der Heide has suggested identifying the copyist of the text as copyist B of BrusBR 5557, namely the one who added the eight Busnoys motets. ${ }^{82}$ However, this identification does not bear scrutiny. While the lettre bourguignonne of $\mathrm{NapBN} 40$ is a cursiva tending towards the formata rather than a simple libraria, the script of the eight motets can rather be described as a currens. Furthermore, the general appearance as well as individual letters (the ductus of the ' $\mathrm{f}$ ', the shape of the final 's' and the consistently open loop of the 'b', to mention but a few) show that the hand cannot be identified as that of NapBN 40. The dedicatory epigram written on $\mathrm{f} .64 \mathrm{v}$ was added by yet another hand, possibly at a later stage.

Text underlay is spacious, with a general sense of coordination between phrases of music and phrases of text. The text is underlaid beneath the music in a single line, and generally is confined within the length of the staves, with the exceptions of the first line of $f$. 5 r, where the two syllables $b i$ and $l i$ of the word invisibili|um are copied after the end of the stave; f. 24v, where at the fifth line, the entire word sed(es) is placed under the custos; and f. 55r, where the second syllable of Igne is placed after the end, though there the stems of the notes copied in the stave below invade the

81 Milsom notes that in the correction made on the first line of the second contratenor at $\mathrm{f}$. 61r, where a seminimina with a punctum additionis is added on an erasure, the dot of addition is above the stave line, contrary to the practice of scribe A, suggesting, therefore, that this correction, at least, was entered by someone, such as B, who usually notated the dots above the stave line. Ibid., p. 207.

82 K. van der Heide, 'New Claims', p. 29. 
space allocated to the text and force the scribe to exceed the length of the stave. This avoidance of collision between text and stems recurs throughout the manuscript and undoubtedly shows how the scribes were concerned with presenting a page that was visually appealing.

The manuscript presents different paratexts: the most common are voice-designation rubrics, found in all the voices but the discantus; tacet, which are always accompanied by the indication of what portion of the text the voice is silent, and never with the indication of which voice is involved; and verte folium, which in almost all cases is present in more than one voice on the same opening. Another paratext often present is the rubric Osanna ut prius or ut supra, indicating the repetition of the first Osanna. The textual canons of the tenor are copied at the beginning of every movement, with the single exception of the first Mass's Agnus Dei.

Throughout the manuscript, the music is organised to require page turns only between sections, and movements tend to follow similar patterns in terms of the organisation of sections and openings. The Kyrie consistently occupies two openings for the first five Masses, with the Christe section copied together with one of the two Kyries on the same opening, and three in the last setting. The Gloria takes up two openings in Mass I and V, and three in the others. As one can see from the inventory (see Appendix 3), the first section of the movement is copied alone on one opening, the second opening starts with the Qui tollis or the Domine fili section, and the third opening is occupied mostly by the Cum Sancto Spiritu, and only in one instance by the Tu solus. The Credo is consistently copied on three openings, apart from the first setting, in which it takes up only two. Usually, the Patrem omnipotentem, as occurs also with the first section of the Gloria, is copied on one opening as a single section, with the exception of the first setting, where it appears alongside the Crucifixus. There is some variance with regard to which sections occupy the remaining openings; most notably, the fourth and fifth settings seem to have on the second opening different portions of the text apparently copied to be sung simultaneously in different voices, a practice known as telescoped text, which can be often found in English repertory.

The Sanctus is equally organised on two openings in Masses I, V and VI, and three openings in Masses II, III and IV. Masses I and VI have on the first opening both the Sanctus and the Pleni, while the others have just the Sanctus. The second opening contains the Pleni and the first Osanna in Masses II, III and IV, and the third opening has the Benedictus as well as the second Osanna, when it is not marked as ut supra. The first setting has in the second opening the two Osanna and the Benedictus, while the fifth has the three sections: Pleni, first Osanna and Benedictus, with the second Osanna ut supra. The Agnus Dei is consistently written on two openings, with the Agnus I on its own in the first opening of Masses I-IV, and with Masses I and III having a separate section for the Dona nobis. 
The end of a section is consistently marked with a double barline, usually black, even for sections where the tenor is silent, entirely notated in red ink, except for the end of the Et expecto section in the discantus at $\mathrm{f}$. $5 \mathrm{v}$, where it is red. In a single case, at f. 5Ir, the double barline is written after the indication Osanna ut prius in the first contratenor. The beginning of a new section is also marked by the use of blue and red litterae notabiliores, with the single exception of the beginning of the Christe section in the second contratenor at $f$. Ir.

Simple initials appear in all the voices except the tenor, in blue or red ink, like the litterae notabiliores that mark the beginning of a new section. The initials of the discantus introduce the first word of the text that is going to be sung, while the two contratenores have an irregular pattern. Often the initials are for the paratexts indicating the voice designation, with the exception of ff. 19r, 20r, 30r, 35r, 4Ir, 42r, 5Ir, 54r, 55r, 58r, 59r, 6Ir and 63r for both the voices, and ff. 25r, 28r, 33r, 38r and 44r, in which only the first contratenor is not marked by a paratext indicating the voice -name.

The initials of the tenor always introduce the voice designation, and they are far more calligraphic than the initials of the other voices. In most cases, we find a bi-chromatic littera florissa in red and yellow, or black and yellow, except for the initial at $\mathrm{f} .36 \mathrm{v}$, being in red, black, and yellow. In a few cases, the florissa also has a grotesque in the decoration, as in ff. $8 \mathrm{v}, 12 \mathrm{v}, 23 \mathrm{v}, 39 \mathrm{v}, 43 \mathrm{v}, 48 \mathrm{v}, 50 \mathrm{v}$ and $60 \mathrm{v}$; in a single instance, at f. $35 \mathrm{v}$, there is a black and yellow zoomorphic initial representing three fishes. As for the 'resolutiones campaign', the tenor is always introduced by a voice designation rubric consistently lacking the initial throughout the manuscript. The initials were added after the main text was copied, as was usual: in fact, often visible within the initial or near to it is a small sign (in the shape of a 2) signalling to the decorator the need for an initial. Other decorations concerning the text consist of majuscules often embellished in yellow ink; in paratexts, where the text is not confined between the staves, additional hairlines and decorative extensions to descenders and ascenders are often present. 
APPENDIX 2

GATHERING STRUCTURE

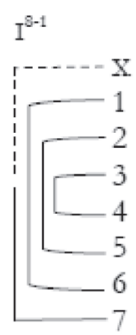

$\mathrm{VT}^{\mathrm{B}}$

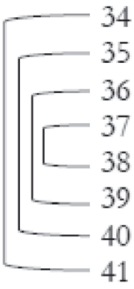

II ${ }^{8-1}$

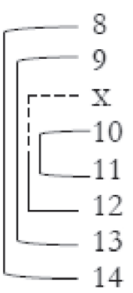

$\mathrm{VII}^{\mathrm{B}-2}$

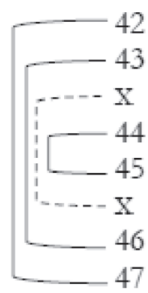

III ${ }^{8-1}$

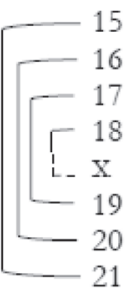

VIII ${ }^{3-1}$

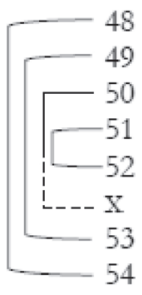

$\mathrm{IV}^{3-2}$

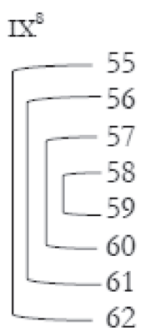

$\mathrm{V}^{8-2}$

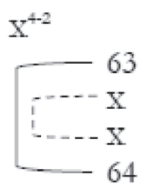


APPENDIX 3

INVENTORY

\begin{tabular}{|c|c|c|}
\hline FOLIO & Setting / Movement & Note \\
\hline $1 \mathrm{r}-9 \mathrm{v}$ & Missa I L'bomme l'homme & \\
\hline $1 r-2 r$ & KYRIE & \\
\hline $1 \mathrm{r}$ & Kyrie I - Christe & Missing D and T \\
\hline $1 \mathrm{v}-2 \mathrm{r}$ & Kyrie II & \\
\hline $2 v-4 r$ & GLORIA & \\
\hline $2 \mathrm{v}-3 \mathrm{r}$ & Et in terra pax & \\
\hline $3 \mathrm{v}-4 \mathrm{r}$ & Qui tollis - Cum sancto spiritu & \\
\hline $4 v-6 r$ & Credo & \\
\hline $4 \mathrm{v}-5 \mathrm{r}$ & Patrem omnipotentem - Crucifixus & \\
\hline $5 v-6 r$ & Et in spiritum - Et expecto & \\
\hline 6v-8r & SANCtUS & \\
\hline $6 v-7 r$ & Sanctus - Pleni & \\
\hline $7 \mathrm{v}-8 \mathrm{r}$ & Osanna I - Benedictus - Osanna II & \\
\hline $8 v-9 v$ & Agnus DeI & \\
\hline $8 \mathrm{v}-9 \mathrm{r}$ & Agnus I & \\
\hline $9 \mathrm{v}$ & Agnus II - Agnus III - Dona nobis & Missing Ct I and II \\
\hline $10 r-21 v$ & Missa II L'homme armé & \\
\hline $10 r-11 r$ & KYRIE & \\
\hline $10 \mathrm{r}$ & Kyrie I & Missing $\mathrm{D}$ and $\mathrm{T}$ \\
\hline $10 \mathrm{v}-11 \mathrm{r}$ & Christe - Kyrie II & \\
\hline $11 v-13 v$ & GLORIA & \\
\hline $11 \mathrm{v}-12 \mathrm{r}$ & Et in terra pax & \\
\hline $12 \mathrm{v}-13 \mathrm{r}$ & Qui tollis & \\
\hline $13 \mathrm{v}$ & Cum sancto spiritu & Single page layout \\
\hline $14 \mathrm{r}$ & Blank & \\
\hline $14 v-16 v$ & Credo & \\
\hline $14 \mathrm{v}-15 \mathrm{r}$ & Patrem omnipotentem & \\
\hline $15 \mathrm{v}-16 \mathrm{r}$ & Crucifixus & \\
\hline $16 \mathrm{v}$ & Et una sanctam & Single page layout \\
\hline $17 \mathrm{r}$ & Blank & \\
\hline $17 v-20 r$ & Sanctus & \\
\hline $17 \mathrm{v}-18 \mathrm{r}$ & Sanctus & \\
\hline $18 \mathrm{v}-19 \mathrm{r}$ & Pleni - Osanna I & \\
\hline
\end{tabular}




\begin{tabular}{|c|c|c|}
\hline $19 \mathrm{v}-20 \mathrm{r}$ & Benedictus & [Osanna ut supra] - Tenor tacet \\
\hline $20 v-21 v$ & Agnus DeI & \\
\hline $20 \mathrm{v}-21 \mathrm{r}$ & Agnus I & \\
\hline $21 \mathrm{v}$ & Agnus II - Agnus III & Missing Ct I and II \\
\hline $22 r-31 v$ & MisSA III Doibt on doubter & \\
\hline $22 r-23 r$ & KYRIE & \\
\hline $22 \mathrm{r}$ & Kyrie I & Missing $\mathrm{D}$ and $\mathrm{T}$ \\
\hline $22 v-23 r$ & Christe - Kyrie II & \\
\hline $23 v-26 r$ & GLORIA & \\
\hline $23 \mathrm{v}-24 \mathrm{r}$ & Et in terra pax & \\
\hline $24 v-25 r$ & Domine fili-Qui tollis & Domine duo D-Ct1 \\
\hline $25 v-26 r$ & Cum sancto spiritu & \\
\hline $26 v-28 r$ & Credo & \\
\hline $26 \mathrm{v}-27 \mathrm{r}$ & Patrem omnipotentem & \\
\hline $27 \mathrm{v}$ & Et incarnatus est - Et resurrexit & Missing Ct I and II \\
\hline $28 \mathrm{r}$ & Qui ex patre - Et expecto & Missing $\mathrm{D}$ and $\mathrm{T}$ \\
\hline $28 v-30 r$ & SANCTUS & \\
\hline $28 v-29 r$ & Sanctus & \\
\hline $29 \mathrm{v}$ & Pleni - Osanna I & Missing Ct $\mathrm{I}$ and $\mathrm{II}$ \\
\hline $30 \mathrm{r}$ & Benedictus - Osanna II & Missing $\mathrm{D}$ and $\mathrm{T}$ \\
\hline $30 v-31 v$ & Agnus DeI & \\
\hline $30 \mathrm{v}-31 \mathrm{r}$ & Agnus I & \\
\hline $31 \mathrm{v}$ & Agnus II - Agnus III - Dona nobis & Missing $\mathrm{Ct}_{\mathrm{I}}$ and $\mathrm{II}$ \\
\hline $32 r-43 v$ & MIssa IV On a fait par tout crier & \\
\hline $32 r-33 r$ & KYRIE & \\
\hline $32 \mathrm{r}$ & Kyrie I & Missing $\mathrm{D}$ and $\mathrm{T}$ \\
\hline $32 v-33 r$ & Christe - Kyrie II & \\
\hline $33 v-36 r$ & GLORIA & \\
\hline $33 v-34 r$ & Et in terra pax & \\
\hline $34 v-35 r$ & Domine fili-Qui tollis & \\
\hline $35 \mathrm{v}-36 \mathrm{r}$ & Tu solus & \\
\hline $36 v-39 r$ & Credo & \\
\hline $36 v-37 r$ & Patrem omnipotentem & \\
\hline $37 v-38 r$ & $\begin{array}{l}\text { Et incarnatus est }(\mathrm{D} / \mathrm{Ct} 1)-\text { Crucifixus } \\
(\mathrm{Ct} 2)-\text { Et ascendit }(\mathrm{D} / \mathrm{Ct} 2)-\text { Et in spiritum } \\
\text { sanctum }(\mathrm{Ct} 1)\end{array}$ & \\
\hline $38 v-39 r$ & Confiteor & \\
\hline
\end{tabular}




\begin{tabular}{|c|c|c|}
\hline $39 v-42 r$ & SANCtus & \\
\hline $39 \mathrm{v}-40 \mathrm{r}$ & Sanctus & \\
\hline $40 \mathrm{v}-41 \mathrm{r}$ & Pleni-Osanna I & \\
\hline $41 v-42 r$ & Benedictus & [Osanna ut supra] - Tenor tace \\
\hline $42 v-43 v$ & Agnus DeI & \\
\hline $42 v-43 r$ & Agnus I & \\
\hline $43 v$ & Agnus II - Agnus III & Missing Ct I and II \\
\hline $44 \mathrm{r}-52 \mathrm{v}$ & Missa V Dun haubregon de fer & \\
\hline $44 r-45 r$ & KYRIE & \\
\hline $44 \mathrm{r}$ & Kyrie I & Missing $\mathrm{D}$ and $\mathrm{T}$ \\
\hline $44 v-45 r$ & Christe - Kyrie II & \\
\hline $45 v-46 r$ & GLORIA & \\
\hline $45 v$ & Et in terra pax & Missing Ct I and II \\
\hline $46 r$ & Qui tollis - Cum sancto spiritu & Missing $\mathrm{D}$ and $\mathrm{T}$ \\
\hline $46 v-49 r$ & Credo & \\
\hline $46 \mathrm{v}-47 \mathrm{r}$ & Patrem omnipotentem & \\
\hline $47 \mathrm{v}-48 \mathrm{r}$ & $\begin{array}{l}\text { Crucifixus }(\mathrm{D} / \mathrm{Ct} 2)-\mathrm{Et} \text { in spiritum } \\
\text { sanctum }(\mathrm{Ct} 1)\end{array}$ & \\
\hline $48 \mathrm{v}-49 \mathrm{r}$ & Confiteor & \\
\hline $49 v-51 r$ & Sanctus & \\
\hline $49 \mathrm{v}-50 \mathrm{r}$ & Sanctus & \\
\hline $50 \mathrm{v}-51 \mathrm{r}$ & Pleni - Osanna I - Benedictus & [Osanna ut supra] \\
\hline $51 \mathrm{v}-52 \mathrm{v}$ & Agnus DeI & \\
\hline $51 v-52 r$ & Agnus I - Agnus II & \\
\hline $52 \mathrm{v}$ & Agnus III & Missing Ct I and II \\
\hline $53 r-63 v$ & $\begin{array}{l}\text { Missa VI L'bomme l'homme l'homme } \\
\text { armé }\end{array}$ & \\
\hline $53 r-55 r$ & KYRIE & \\
\hline $53 r$ & Kyrie I & Missing D and $\mathrm{T}$ \\
\hline $53 \mathrm{v}-54 \mathrm{r}$ & Christe & \\
\hline $54 \mathrm{v}-55 \mathrm{r}$ & Kyrie II & \\
\hline $55 \mathrm{v}-58 \mathrm{r}$ & GLORIA & \\
\hline $55 \mathrm{v}-56 \mathrm{r}$ & Et in terra pax & \\
\hline $56 v-57 v$ & Domine deus & \\
\hline $57 \mathrm{v}-58 \mathrm{r}$ & Cum sancto spiritu & \\
\hline $58 v-61 r$ & Credo & \\
\hline $58 v-59 r$ & Patrem omnipotentem & \\
\hline
\end{tabular}




\begin{tabular}{|l|l|l|}
\hline $59 \mathrm{v}-60 \mathrm{r}$ & Crucifixus & \\
\hline $60 \mathrm{v}-61 \mathrm{r}$ & Confiteor & \\
\hline $\mathbf{6 1 v}-63 \mathbf{r}$ & SANCTUs & \\
\hline $61 \mathrm{v}-62 \mathrm{r}$ & Sanctus - Pleni & \\
\hline $62 \mathrm{v}-63 \mathrm{r}$ & Osanna - Benedictus & [Osanna ut supra] \\
\hline $\mathbf{6 3 v}$ & AGNus DeI & \\
\hline $63 \mathrm{v}$ & Agnus I & Missing Ct I and II \\
\hline $64 \mathrm{v}$ & Blank & \\
\hline $64 \mathrm{r}$ & Dedication-Coat of arms & \\
\hline
\end{tabular}

\section{APPENDIX 4 \\ PARATEXTS}

\begin{tabular}{|c|c|c|c|}
\hline Folio & Stave & Voice & ParateXt \\
\hline $2 \mathrm{v}$ & 5 & $\mathrm{D}$ & Verte folium \\
\hline $2 \mathrm{v}$ & 10 & $\mathrm{~T}$ & $\begin{array}{l}\text { Canon | Bis vicibus binis gradatim vir In ordine scandit | Ut } \\
\text { prius incessit ipse Retrograditur }\end{array}$ \\
\hline $4 v$ & 10 & $\mathrm{~T}$ & Crucifixus $\mid$ tacet \\
\hline $4 \mathrm{v}$ & 11 & $\mathrm{~T}$ & $\begin{array}{l}\text { Canon | Bis vicibus binis gradatim vir in ordine scandit } \mid \mathrm{Ut} \\
\text { prius incessit ipse Retrograditur }\end{array}$ \\
\hline $5 r$ & 6 & CtA & Verte folium \\
\hline $6 v$ & 6 & $\mathrm{D}$ & Verte folium \\
\hline $6 \mathrm{v}$ & 9 & $\mathrm{~T}$ & Pleni $\mid$ tacet \\
\hline $6 v$ & 10 & $\mathrm{~T}$ & $\begin{array}{l}\text { Canon | Bis vicibus binis gradatim vir in ordie scandit | Ut } \\
\text { prius incessit ipse Retrograditur }\end{array}$ \\
\hline $7 \mathrm{v}$ & 10 & $\mathrm{~T}$ & Benedictus $\mid$ tacet \\
\hline $8 \mathrm{v}$ & 4 & $\mathrm{D}$ & Verte folium \\
\hline $9 \mathrm{r}$ & 4 & CtA & Verte folium \\
\hline $9 \mathrm{r}$ & 10 & $\mathrm{CtB}$ & Verte foliū \\
\hline $10 \mathrm{r}$ & 5 & CtA & Verte folium \\
\hline $10 \mathrm{v}$ & 9 & $\mathrm{~T}$ & \begin{tabular}{|l|l} 
Xpriste & tacet \\
\end{tabular} \\
\hline $11 \mathrm{v}$ & 7 & $\mathrm{D}$ & Verte folium \\
\hline $11 \mathrm{v}$ & $10-11$ & $\mathrm{~T}$ & $\begin{array}{l}\text { Canon | Ambulat hic armatus homo. Verso quoque vultu } \\
\text { | arma Rapit. dextram sequitur. sic ut vice versa | ad levam } \\
\text { scandat. vultus sumendo priores | Ipse retrograditur. } \\
\text { Respondent ultima primis }\end{array}$ \\
\hline $12 \mathrm{v}$ & 7 & $\mathrm{D}$ & Verte folium \\
\hline $13 r$ & 6 & CtA & Verte folium \\
\hline $13 r$ & 12 & $\mathrm{CtB}$ & Verte folium \\
\hline
\end{tabular}




\begin{tabular}{|c|c|c|c|}
\hline $14 \mathrm{v}$ & 8 & $\mathrm{D}$ & Verte folium \\
\hline $14 \mathrm{v}$ & $11-12$ & $\mathrm{~T}$ & $\begin{array}{l}\text { Canon | Ambulat hic armatus homo. Verso quoque vultu } \\
\text { | arma Rapit. dextram sequitur. sic ut vice versa | ad levam } \\
\text { scandat. vultus sumendo priores | Ipse Retrograditur. } \\
\text { Respondent ultima primis }\end{array}$ \\
\hline $17 \mathrm{v}$ & 5 & $\mathrm{D}$ & Verte folium \\
\hline $17 \mathrm{v}$ & 10 & $\mathrm{~T}$ & $\begin{array}{l}\text { Canon | Ambulat hic armatus homo. Verso quoque vultu } \\
\text { | arma Rapit. dextram sequitur, sic ut vice versa | ad levam } \\
\text { scandat. vultus sumendo priores | Ipse retrograditur. } \\
\text { Respondent ultima primis }\end{array}$ \\
\hline $18 \mathrm{r}$ & 9 & $\mathrm{CtB}$ & Verte folium \\
\hline $18 \mathrm{v}$ & 8 & $\mathrm{~T}$ & \begin{tabular}{|l|l|} 
Pleni & tacet
\end{tabular} \\
\hline $19 \mathrm{r}$ & 5 & $\mathrm{Ct} A$ & Verte folium \\
\hline $19 \mathrm{r}$ & 10 & $\mathrm{CtB}$ & Verte folium \\
\hline $19 \mathrm{v}$ & 4 & $\mathrm{D}$ & Osanna ut supra \\
\hline $20 \mathrm{r}$ & 4 & $\mathrm{CtA}$ & Osanna ut supra \\
\hline $20 \mathrm{r}$ & 8 & $\mathrm{CtB}$ & Osanna ut supra \\
\hline $20 v$ & 6 & $\mathrm{D}$ & Verte folium \\
\hline $20 v$ & $9-10$ & $\mathrm{~T}$ & $\begin{array}{l}\text { Canon | Ambulat hic armatus homo. Verso quoque vultu | arma } \\
\text { Rapit. dextram sequitur, sic ut vice versa | ad levam scandat. vultus } \\
\text { sumendo priores | Ipse retrograditur. Respondent ultima primis }\end{array}$ \\
\hline $21 \mathrm{r}$ & 5 & CtA & Verte folium \\
\hline $21 v$ & 7 & $\mathrm{~T}$ & Agnus | tacet \\
\hline $22 \mathrm{r}$ & 5 & CtA & Verte folium \\
\hline $22 \mathrm{r}$ & 11 & $\mathrm{CtB}$ & Verte folium \\
\hline $23 \mathrm{v}$ & 7 & $\mathrm{D}$ & Verte folium \\
\hline $23 \mathrm{v}$ & $10-11$ & $\mathrm{~T}$ & $\begin{array}{l}\text { Canon | Sic metuendus eat gressum Repedendo ne pausat } \\
\mid \text { demum scandendo per dyatessaron it | Ast ubi conscendit } \\
\text { vice mox versa Remeabit | descensus finem per dyapente facit }\end{array}$ \\
\hline $24 \mathrm{r}$ & 6 & $\mathrm{CtA}$ & Verte folium \\
\hline $24 \mathrm{r}$ & 11 & $\mathrm{CtB}$ & Verte folium \\
\hline $24 v$ & 8 & $\mathrm{D}$ & Verte folium \\
\hline $24 \mathrm{v}$ & 9 & $\mathrm{~T}$ & Domine fili tacet \\
\hline $26 v$ & 7 & $\mathrm{D}$ & Verte folium \\
\hline $26 v$ & $10-11$ & $\mathrm{~T}$ & $\begin{array}{l}\text { Canon | Sic metuendus eat gressu } m \text { Repedendo ne pausat } \\
\mid \text { demu } m \text { scandendo per dyatessaron it | Ast ubi conscendit } \\
\text { vice mox versa Remeabit | Descensus finem per dyapente facit }\end{array}$ \\
\hline $27 \mathrm{r}$ & 6 & CtA & Verte folium \\
\hline $27 v$ & 9 & $\mathrm{D}$ & Verte folium \\
\hline $27 v$ & 10 & $\mathrm{~T}$ & Et incarnat $u s \mid$ tacet \\
\hline
\end{tabular}




\begin{tabular}{|c|c|c|c|}
\hline $28 \mathrm{r}$ & 6 & $\mathrm{CtB}$ & Qui ex patre tacet \\
\hline $28 v$ & 6 & $\mathrm{D}$ & Verte folium \\
\hline $28 v$ & $9-10$ & $\mathrm{~T}$ & $\begin{array}{l}\text { Canon | Sic metuendus eat gressum Repedendo ne pausat } \\
\mid \text { demum scandendo per dyatessaron it | Ast ubi conscendit } \\
\text { vice mox versa Remeabit | Descensus finem per dyapente facit }\end{array}$ \\
\hline $29 r$ & 6 & CtA & Verte folium \\
\hline $29 r$ & 10 & $\mathrm{CtB}$ & Verte folium \\
\hline $29 \mathrm{v}$ & 7 & $\mathrm{D}$ & Verte folium \\
\hline $29 \mathrm{v}$ & 8 & $\mathrm{~T}$ & Pleni tacet \\
\hline $30 r$ & 7 & $\mathrm{CtB}$ & Benedictus tacet \\
\hline $30 \mathrm{v}$ & 6 & $\mathrm{D}$ & Verte folium \\
\hline $30 v$ & $10-11$ & $\mathrm{~T}$ & $\begin{array}{l}\text { Canon | Sic metuendus eat gressum Repedendo ne pausat } \\
\text { | demum scandendo per dyatessaron it | Ast ubi conscendit } \\
\text { vice mox versa Remeabit | Descensus finem per dyapente facit }\end{array}$ \\
\hline $31 \mathrm{r}$ & 5 & CtA & Verte folium \\
\hline $31 \mathrm{v}$ & 10 & $\mathrm{~T}$ & Agnus tacet \\
\hline $33 v$ & 6 & $\mathrm{D}$ & Verte folium \\
\hline $33 v$ & 11 & $\mathrm{~T}$ & $\begin{array}{l}\text { Canon | Buccina clangorem voces vertendo Reflectit | Subque } \\
\text { gradu Reboat iterum clamando quaterno }\end{array}$ \\
\hline $34 \mathrm{r}$ & 5 & CtA & Verte folium \\
\hline $34 \mathrm{r}$ & 11 & $\mathrm{CtB}$ & Verte folium \\
\hline $34 \mathrm{v}$ & 7 & $\mathrm{D}$ & Verte folium \\
\hline $34 v$ & 8 & $\mathrm{~T}$ & Domine fili tacet \\
\hline $35 \mathrm{r}$ & 10 & $\mathrm{CtB}$ & Verte folium \\
\hline $36 v$ & 7 & $\mathrm{D}$ & Verte folium \\
\hline $36 v$ & 10 & $\mathrm{~T}$ & $\begin{array}{l}\text { Canon | Buccina clangorem voces vertendo Reflectit | subque } \\
\text { gradu Reboat iterum clamando quaterno }\end{array}$ \\
\hline $37 \mathrm{r}$ & 5 & CtA & Verte folium \\
\hline $37 \mathrm{v}$ & 7 & $\mathrm{D}$ & Verte folium \\
\hline $37 v$ & 8 & $\mathrm{~T}$ & Et incarnatus $\mid$ tacet \\
\hline $39 \mathrm{v}$ & 6 & $\mathrm{D}$ & Verte folium \\
\hline $39 v$ & 10 & $\mathrm{~T}$ & $\begin{array}{l}\text { Canon | Buccina clangorem voces vertendo Reflectit | Subque } \\
\text { gradu Reboat iterum clamando quaterno }\end{array}$ \\
\hline $40 r$ & 5 & CtA & Verte folium \\
\hline $40 \mathrm{v}$ & 7 & $\mathrm{D}$ & Verte folium \\
\hline $40 v$ & 8 & $\mathrm{~T}$ & Pleni tacet \\
\hline $41 v$ & 5 & $\mathrm{D}$ & Osanna ut supra \\
\hline $42 r$ & 4 & CtA & Osanna ut prius \\
\hline $42 r$ & $8-9$ & $\mathrm{CtB}$ & Osanna ut prius \\
\hline $42 v$ & 7 & $\mathrm{D}$ & Verte folium \\
\hline
\end{tabular}




\begin{tabular}{|c|c|c|c|}
\hline $42 \mathrm{v}$ & 10 & $\mathrm{~T}$ & $\begin{array}{l}\text { Canon | Buccina clangorem voces vertendo Reflectit | Subque } \\
\text { gradu Reboat iterum clamando quaterno }\end{array}$ \\
\hline $43 r$ & 11 & $\mathrm{CtB}$ & Verte folium \\
\hline $43 v$ & 8 & $\mathrm{~T}$ & Agnus tacet \\
\hline $44 \mathrm{r}$ & 6 & $\mathrm{CtA}$ & Verte folium \\
\hline $45 v$ & 7 & $\mathrm{D}$ & Verte folium \\
\hline $45 v$ & $10-11$ & $\mathrm{~T}$ & $\begin{array}{l}\text { Canon | Per dyapente sonat subter Remeando lorica | Post } \\
\text { ubi finierit gressum Renovando Resumit | Tu que gradu } \\
\text { sursum cantando Revertere quinto | Principio finem da qui } \\
\text { modularis eundem }\end{array}$ \\
\hline $46 v$ & 6 & $\mathrm{D}$ & Verte folium \\
\hline $46 v$ & $9-10$ & $\mathrm{~T}$ & $\begin{array}{l}\text { Canon | Per dyapente sonat subter Remeando lorica | Post } \\
\text { ubi finierit gressum Renovando Resumit | Tu que gradu } \\
\text { sursum cantando Revertere quinto | Principio finem da qui } \\
\text { modularis eundem }\end{array}$ \\
\hline $47 v$ & 5 & $\mathrm{D}$ & Verte folium \\
\hline $48 \mathrm{r}$ & 5 & CtA & Verte folium \\
\hline $48 \mathrm{r}$ & 11 & $\mathrm{CtB}$ & \begin{tabular}{|l|} 
Verte folium \\
\end{tabular} \\
\hline $49 v$ & 6 & $\mathrm{D}$ & Verte folium \\
\hline $49 v$ & $10-11$ & $\mathrm{~T}$ & $\begin{array}{l}\text { Canon | Per dyapente sonat subter Remeando lorica | Post } \\
\text { ubi finierit gressum Renovando resumit | Tu que gradu } \\
\text { sursum cantando Revertere quinto | Principio finem da qui } \\
\text { modularis eundem }\end{array}$ \\
\hline $50 \mathrm{r}$ & 6 & $\mathrm{CtA}$ & Verte folium \\
\hline $50 \mathrm{r}$ & 12 & $\mathrm{CtB}$ & Verte folium \\
\hline $50 v$ & 10 & $\mathrm{D}$ & Osanna ut supra \\
\hline $50 v$ & 11 & $\mathrm{~T}$ & Pleni tacet $\mid$ Benedict $u s$ tacet \\
\hline $51 \mathrm{r}$ & 8 & CtA & Osanna | ut prius \\
\hline $51 \mathrm{r}$ & 8 & $\mathrm{CtB}$ & \begin{tabular}{|l|l|} 
Pleni & tacet
\end{tabular} \\
\hline $51 \mathrm{r}$ & 12 & $\mathrm{CtB}$ & Benedictus tacet \\
\hline $51 \mathrm{v}$ & 11 & $\mathrm{~T}$ & Agnus tacet \\
\hline $51 \mathrm{v}$ & 12 & $\mathrm{~T}$ & $\begin{array}{l}\text { Canon | Per dyapente sonat subter Remeando lorica | post } \\
\text { ubi finierit gressum Renovando resumit | Tu que gradu } \\
\text { sursu } m \text { cantando Revertere quinto | Principio finem da qui } \\
\text { modularis eundem }\end{array}$ \\
\hline $52 \mathrm{r}$ & 8 & CtA & Verte folium \\
\hline $53 r$ & 5 & CtA & Verte folium \\
\hline $53 r$ & 11 & $\mathrm{CtB}$ & Verte folium \\
\hline $53 \mathrm{v}$ & 5 & $\mathrm{D}$ & Verte folium \\
\hline $54 \mathrm{r}$ & 4 & $\mathrm{CtA}$ & Verte folium \\
\hline
\end{tabular}




\begin{tabular}{|c|c|c|c|}
\hline $54 \mathrm{r}$ & 10 & $\mathrm{CtB}$ & Verte folium \\
\hline $55 \mathrm{v}$ & 8 & $\mathrm{D}$ & Verte folium \\
\hline $55 \mathrm{v}$ & 13 & $\mathrm{~T}$ & $\begin{array}{l}\text { Canon | Arma virum que cano vincor que per arma virum que } \\
\text { | Alterni gradimur hic ubi signo tacet | Sub hychanos hypaton } \\
\text { oritur sic undique pergit | Visceribus propriis conditur Ille } \\
\text { meis }\end{array}$ \\
\hline $56 \mathrm{v}$ & 7 & $\mathrm{D}$ & Verte folium \\
\hline $58 \mathrm{v}$ & 8 & $\mathrm{D}$ & Verte foliū \\
\hline $58 v$ & 12 & $\mathrm{~T}$ & $\begin{array}{l}\text { Canon | Arma virum que cano vincor que per arma virumque } \\
\text { | Alterni gradimur hic ubi signo tacet | Sub hychanos hypaton } \\
\text { oritur sic undique pergit | Visceribus propriis conditur Ille } \\
\text { meis }\end{array}$ \\
\hline $59 \mathrm{v}$ & 8 & $\mathrm{D}$ & Verte folium \\
\hline $61 \mathrm{v}$ & 7 & $\mathrm{D}$ & Verte folium \\
\hline $61 \mathrm{v}$ & $12-13$ & $\mathrm{~T}$ & $\begin{array}{l}\text { Canon | Arma virum que cano vincor que per arma virum que } \\
\text { | Alterni gradimur hic ubi signo tacet | Sub hychanos hypaton } \\
\text { oritur sic undique pergit | Visceribus propriis conditur Ille meis }\end{array}$ \\
\hline $62 r$ & 7 & $\mathrm{CtA}$ & Verte folium \\
\hline $62 \mathrm{v}$ & 6 & $\mathrm{D}$ & Osanna ut supra \\
\hline $62 v$ & 12 & $\mathrm{~T}$ & Benedictus tacet \\
\hline $63 r$ & 6 & CtA & Osanna ut | Prius \\
\hline $63 r$ & 10 & $\mathrm{CtB}$ & Benedict $u$ s tacet \\
\hline $63 \mathrm{v}$ & 6 & $\mathrm{D}$ & Verte folium \\
\hline $63 \mathrm{v}$ & $10-11$ & $\mathrm{~T}$ & $\begin{array}{l}\text { Canon | Arma virum que cano vincor que per arma virum que } \\
\text { | Alterni gradimur hic ubi signo tacet | Sub hychanos hypaton } \\
\text { oritur sic undique pergit | Visceribus propris conditur Ille meis }\end{array}$ \\
\hline $64 v$ & $1-5$ & & $\begin{array}{l}\text { Ad serenissimam | Ungarie Reginam | Regia pro<ge>nies regi } \\
\text { nupta beatrix | Qua sub sole viget nulla probandi magis, | Te } \\
\text { tua virtutum series lustrata per orbem | Nunciat; ut nostris sis } \\
\text { quoque nota locis, | Tu modo divinos cultus regionibus istis | } \\
\text { Extollens, cantus aducis ipsa modos, | O pietas miranda nimis } \\
\text { laudanda que, maius | Hoc regina tibi quod decus esse potest, } \\
\text { | Rex hostes fidei vincit, Regina colendo | Magnificat sanctam } \\
\text { sublevat atque fidem, | Quam bene concordi iunxerunt } \\
\text { numina lecto | Quos natura facit moribus esse pares, | Hinc } \\
\text { licet ignotus, dominam te munere tantam | Ausus adire fui, } \\
\text { servulus ipse tuus, | Charolus hoc princeps quondam gaudere } \\
\text { solebat | Conveniet, certum est, moribus idque tuis, | Hoc } \\
\text { capias igitur quaeso, videas que libenter; | Munus ab ignoto } \\
\text { saepe placere solet, | I<a>m v<al>eas foelix cum caro coniuge } \\
\text { semper | Augeat in nostram fortis uterque fidem. }\end{array}$ \\
\hline
\end{tabular}




\section{APPENDIX 5}

\section{DEVISES OF THE DE JANLY FAMILY IN LONDON, BRITISH LIBRARY, C.3.D.2}

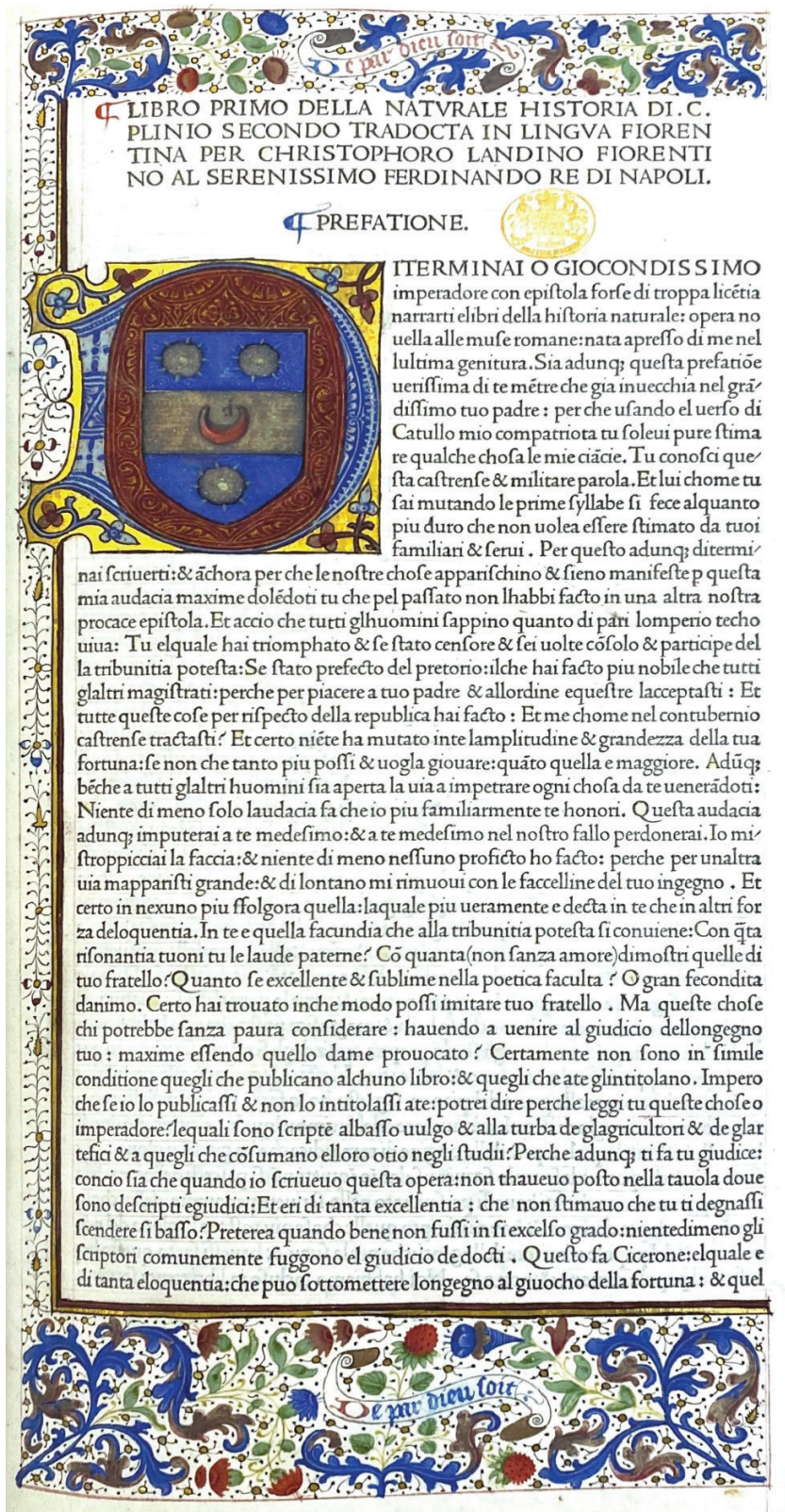

London, British Library, C.3.d.2., first page of the Libro Primo with the devises of the Janly family in the border decoration and the coat of arms in the illuminated initial.

(C) British Library Board 


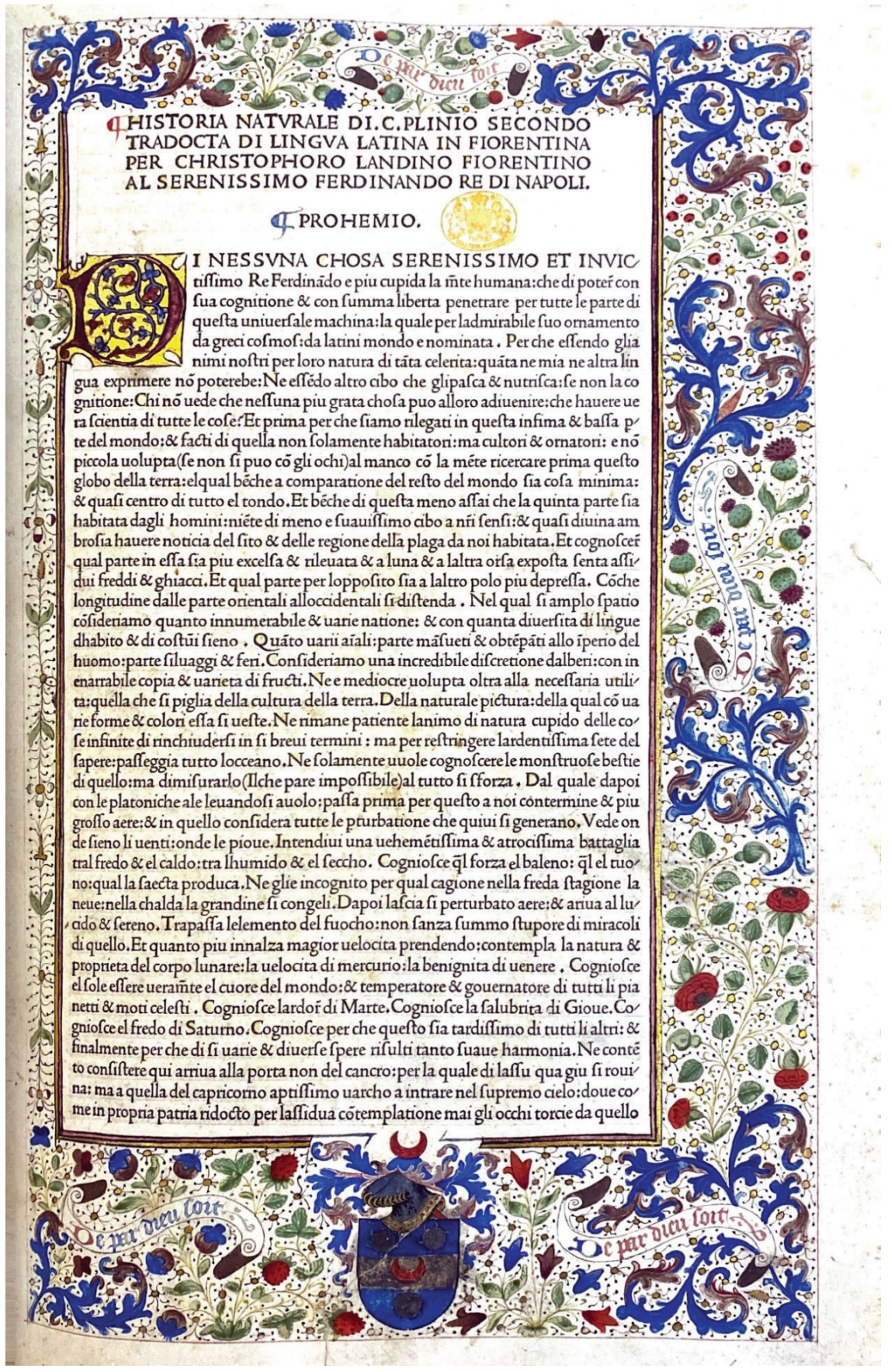

London, British Library, C.3.d.2., first page of the Prohemio with the devise of the Janly family repeated four times in the decoration, and the coat of arms in the bas-de-page.

(C) British Library Board 


\section{BIBLIOGRAPHY}

Alden, Jane. Songs, Scribes, and Society. The History and Reception of the Loire Valley Chansonniers. New York: Oxford University Press, 2010.

Bárány, Attila. 'King Matthias and the Western European Powers.' In: Matthias Rex 1458 -I490 - Hungary at the Dawn of the Renaissance, eds. István Draskóczy, Iván Horváth, Gábor Kiss Farkas, Ernő Marosi and Vilmos Voigt. Budapest: ELTE, Centre des hautes études de la Renaissance, 2013.

Barre, Louis-François-Joseph de la. Mémoires pour servir à l'histoire de France et de Bourgogne. Paris: Julien-Michel Gandouin et Pierre-François Giffart, I729.

Beaune, Henri and Jules D’Arbaumont. La noblesse aux états de Bourgogne de 1350 à 1789 . Dijon: La Marche, I864.

Belozerskaya, Marina. Rethinking the Renaissance. Burgundian Arts across Europe. Cambridge: Cambridge University Press, 2002.

Bessey, Valérie, Véronique Flammang and Émilie Lebailly, eds. Comptes de l'Argentier de Charles le Téméraire, duc de Bourgogne. Vol. 3/. Paris: Boccard, 2008.

Bessey, Valérie and Sébastien Hamel, eds. Comptes de l'Argentier de Charles le Téméraire, duc de Bourgogne. Vol. 4. Paris: Boccard, 2009.

Bigarne, Charles. 'Les capitaines du château de Beaune, études généalogiques.' Société d'histoire, d'archéologie et de littérature de l'arrondissement de Beaune. Mémoires année I886 (I887): 47-I66.

Borghetti, Vincenzo. 'Music and the Representation of Princely Power in the Fifteenth and Sixteenth Century.' Acta Musicologica 80, no. 2 (2008): I79-2I4.

Borsook, Eva. 'Filippo Strozzi and the Two Plinys: Civic Pride, Diplomacy, and Private Taste in Quattrocento Naples and Florence.' I Tatti Studies in the Italian Renaissance 23, no. I (2020): 77-99.

Buettner, Brigitte. 'Past Presents: New Year's Gifts at the Valois Courts, ca. I40o.' The Art Bulletin 83, no. 4 (200I): 598-625.

Caraci, Maria. 'Johannes Ockeghem. Actes du XL Colloque international d'Études humanistes, edités par Philippe Vendrix, Paris, Klinksieck, 1998. Antoine Busnois, Method, Meaning and Context in Late Medieval Music, ed. Paula Higgins, Oxford, Clarendon Press, 1999.' Philomusica on-line I, no. I (200I).

Caron, Marie-Thérèse. Les voeux du Faisan, noblesse en fête, esprit de croisade. Le manuscrit Français IIS94 de la Bibliothèque Nationale de France. Turnhout: Brepols, 2003.

Cohen, Judith. The Six Anonymous L'homme armé Masses in Naples, Biblioteca Nazionale, MS VI E 40. Dallas: American Institute of Musicology, 1968.

Commynes, Philippe de. The Historical Memoirs of Philip De Comines. London: William McDowall, i8I7.

Csapodi, Csaba. 'La biblioteca di Beatrice d'Aragona, moglie di Mattia Corvino.' In: Italia ed Ungheria: dieci secoli di rapporti letterari, ed. Mátyás Horányi, II3-I33. Budapest: Akadémiai Kiadó, 1967.

Expilly, Jean Joseph de. Dictionnaire géographique, historique et politique des Gaules et de la France. Vol. 6. Amsterdam: Desaint \& Saillant, I770.

Farbaky, Péter. 'Patrons and Patterns: The Connection between the Aragon Dynasty of Naples and the Hungarian Court of Matthias Corvinus.' Radovi Instituta za povijest umjetnosti 4I (20I7): 23-3I. 
Frońska, Joanna. 'London, British Library, Royal Ms 20 A. XVI.' In: The Production and Reading of Music Sources. Mise-en-page in Manuscripts and Printed Books Containing Polyphonic Music, I480-I530, eds. Thomas Schmidt and Christian Thomas Leitmeir, 263-283. Turnhout: Brepols, 2018.

Gachard, Louis Prosper. 'Analectes historiques, Cinquième série.' Compte-rendu des séances de la commission royale d'histoire 9 (I857): $103-256$.

Geliot, Louvan. Le vraye et parfaite science des armoires ou l'indice armorial de feu maistre. Paris: Frederic Leonard, I664.

Giller, Don. 'The Naples L'Homme Armé Masses and Caron: A Study in Musical Relationship.' Current Musicology 32 (198I): 7-28.

Greve, Anke and Émilie Lebailly, eds. Comptes de l'Argentier de Charles le Téméraire, duc de Bourgogne. Vol. I. Paris: Boccard, 200I.

Greve, Anke and Émilie Lebailly, eds. Comptes de l'Argentier de Charles le Téméraire, duc de Bourgogne. Vol. 2. Paris: Boccard, 2002.

Haggh, Barbara. 'Letter from Barbara Helen Haggh.' Journal of the American Musicological Society 40, no. I (1987): I39-I43.

Haggh, Barbara. 'Charles de Clerc, Seigneur de Bouvekercke, and Two Manuscripts: Brussels, Bibliothèque Royale de Belgique, MS 215-16, and Naples, Biblioteca Nazionale, MS VI E 40.' In: The Burgundian-Habsburg Court Complex of Music Manuscripts (I500-I535) and the Workshop of Petrus Alamire, eds. Bruno Bouckaert and Eugeen Schreurs, 185-202. Leuven: Alamire Music Publishers, 2003.

Lewis, Katherine J. 'Women and Power.' In: Historians on John Gower, eds. Stephen H. Rigby and Echard Siân, 323-350. Cambridge: D.S. Brewer, 2019.

Long, Michael. 'Arma virumque cano: Echoes of a Golden Age.' In: Antoine Busnoys: Method, Meaning, and Context in Late Medieval Music, ed. Paula Higgins, 133-154. Oxford: Clarendon Press, 1999.

Lütteken, Laurenz. 'Ritual und Krise. Die neapolitanischen "L'homme armé"-Zyklen und die Semantik der Cantus firmus-Messe.' In: Musik als Text. Bericht über den Internationalen Kongreß der Gesellschaft für Musikforschung. Freiburg im Bresgau 1993, eds. Hermann Danuser and Tobias Plebuch, 207-218. Kassel: Bärenreiter, 1998.

Magny, Louis de. La science du blason, accompagnée d'un armorial général des familles nobles de l'Europe. Paris: Institut Heraldique, I858.

Martin, Jean. 'L'église cathédrale Saint-Vincent de Chalon-sur-Saône. Pierre tombales \& documents historiques.' In: Mémoires de la société d'histoire et d'archéologie de Chalon-sur-Saône, I-I25. Chalon-sur-Saône: Émile Bertrand, I906.

Mauss, Marcel. The Gift. The Form and Reason for Exchange in Archaic Societies. London: Routledge, 2002.

Michon, Louis. Inventaire-sommaire des archives départementales de Saône-et-Loire antérieures à I790. Ire partie. Archives civiles. Séries D-E. Macon: Protat, I877.

Milano, Ernesto. 'I codici corviniani conservati nelle biblioteche italiane.' In: Nel segno del corvo. Libri e miniature della biblioteca di Mattia Corvino, 65-93. Modena: Il Bulino, 2002.

Millar, Alistair. 'Olivier de la Marche and the Court of Burgundy, c.I425-I5O2.' PhD dissertation (The University of Edinburgh, 1996).

Milsom, John. 'Dots before the Eyes: Regional Preferences for the Placement of Dots of Addition.' Tijdschrift van de Koninklijke Vereniging voor Nederlandse Muziekgeschiedenis 67, no. I/2 (2OI7): I9I-2II. 
Palliot, Pierre. Le Parlament de Bourgongne, son origine, son etablissement, et son progrés. Dijon: Pierre Palliot, I649.

Paul, Nicholas L. To Follow in Their Footsteps. The Crusades and Family Memory in the High Middle Ages. Ithaca: Cornell University Press, 2012.

Plamenac, Dragan. 'La chanson de L'homme armé et le MS VI.E.40 de la Bibliothèque Nationale de Naples.' In: Annales de la Féderation archéologique et historique de Belgique. Congrès jubilaire sous les auspices des Ministeres des Sciences et Arts, des Affaires étrangeres et de la ville de Bruges, 229-230. Bruges: Féderation Archéologique et Historique de Belgique, 1926.

Plamenac, Dragan. 'Zur “L'homme armé"-Frage.' Zeitschrift für Musikwissenschaft II (I929): $376-383$.

Rees, Valery. "'A Woman of Valour”: Towards a Reappraisal of the Presence of Beatrix of Aragon in the Hungarian Court.' In: Matthias Rex I458-I490 - Hungary at the Dawn of the Renaissance, eds. István Draskóczy, Iván Horváth, Gábor Kiss Farkas, Ernő Marosi and Vilmos Voigt. Budapest: ELTE, Centre des hautes études de la Renaissance, 2013.

Rietstap, Jean-Baptiste. Armorial Général: précédé d'un Dictionnaire des termes du blaison. Gouda: G.B. van Goor Zonen, I884.

Rizzi, Andrea. 'Editing and Translating Pliny in Renaissance Italy: Agency, Collaboration and Visibility.' Renaessanceforum - Journal of Renaissance Studies I4 (2018): II7-I38.

Roover, Florence Edler de. 'New Facets on the Financing and Marketing of Early Printed Books.' Bulletin of the Business Historical Society 27, no. 4 (1953): 222-230.

Saint-Julien, Pierre de. De l'origine des Bourgongnons, et antiquité des estats de Bourgongne. Paris: Nicolas Chesneau, I58I.

Schmidt, Thomas. 'Dedicating Music Manuscripts: On Function and Form of Paratexts in Fifteenth- and Sixteenth-Century Sources.' In 'Cui dono lepidum novum libellum?'. Dedicating Latin Works and Motets in the Sixteenth Century, eds. Ignace Bossuyt, Nele Gabriëls, Dirk Sacré and Demmy Verbeke, 8I-I08. Leuven: Leuven University Press, 2008.

Schmidt, Thomas. 'Making Polyphonic Books in the Late Fifteenth and Early Sixteenth Centuries.' In: The Production and Reading of Music Sources: Mise-en-page in Manuscripts and Printed Books Containing Polyphonic Music, I480-I530, eds. Thomas Schmidt and Christian Thomas Leitmeir, 3-IOo. Turnhout: Brepols, 2018.

Schmidt, Thomas and Christian T. Leitmeir, eds. The Production and Reading of Music Sources. Mise-en-page in Manuscripts and Printed Books Containing Polyphonic Music, I480-I530. Turnhout: Brepols, 2018.

Shephard, Tim. 'Constructing Identities in a Music Manuscript: The Medici Codex as a Gift.' Renaissance Quarterly 63, no. I (2010): 84-I27.

Spitzbarth, Anne-Brigitte. Ambassades et ambassadeurs de Philippe le Bon, troisième duc Valois de Bourgogne (I4I9-I467). Turnhout: Brepols, 2013.

Stein, Henri. Olivier de la Marche. Historien, poète et diplomate Bourguignon. Paris: Picard, I888. Taruskin, Richard. 'Antoine Busnoys and the "L'Homme Armé" Tradition.' Journal of the American Musicological Society 39, no. 2 (1986): 255-293.

Vale, Malcolm G.A. Charles VII. Berkeley-Los Angeles: University of California Press, 1974. van der Heide, Klaas. 'New Claims for a Burgundian Origin of the L'homme armé Tradition, and a Different View on the Relative Positions of the Earlies Masses in the Tradition.' Tijdschrift van de Koninklijke Vereniging voor Nederlandse Muziekgeschiedenis 55, no. I (2005): 3-33.

Wegman, Rob C. 'Musical Offerings in the Renaissance.' Early Music 33, no. 3 (2005): 425-437. 
Wegman, Rob C. 'New Data Concerning the Origins and Chronology of Brussels, Koninklijke Bibliotheek, Manuscript 5557.' Tijdschrift van de Vereniging voor Nederlandse Muziekgeschiedenis 36 (I986): 5-25.

Wijsman, Hanno. Luxury Bound. Illustrated Manuscript Production and Noble and Princely Book Ownership in the Burgundian Netherlands (I400-I550). Turnhout: Brepols, 2010.

Williamson, Magnus, ed. The Eton Choirbook. Facsimile and Introductory Study. Oxford: DIAMM, 2010.

Woodley, Ronald. 'Tinctoris's Italian Translation of the Golden Fleece Statutes: A Text and a (Possible) Context.' Early Music History 8 (1988): 173-244.

Zanovello, Giovanni. "'You Will Take This Sacred Book": The Musical Strambotto as a Learned Gift.' Journal of the Royal Musical Association I4I, no. I (20I6): I-26.

Zemon Davis, Natalie. 'Beyond the Markets: Books as Gifts in Sixteenth-Century France: The Prothero Lecture.' Transactions of the Royal Historical Society 33 (1983): 69-88.

\section{NOWE USTALENIA DOTYCZĄCE POCHODZENIA I PROCESU POWSTAWANIA RĘKOPISU} VI E 40 Z BIBLIOTECA NAZIONALE W NEAPOLU

Ostatnie badania nad rękopisem VI E 40 z Biblioteca Nazionale z Neapolu (I-Nn 40) doprowadziły do identyfikacji herbu znajdującego się na końcu księgi oraz do zaktualizowania jej opisu kodykologicznego. Ten sam herb znajduje się na egzemplarzu druku Historia Naturalis Pliniusza Starszego z I476 r., który należał do mało znanej burgundzkiej rodziny de Janly, nobilitowanej w I poł. XV wieku. Wywodzili się z niej dworzanie i urzędnicy - trzech z nich przedstawiono w artykule, jako potencjalnych pierwszych właścicieli rękopisu I-Nn 40, uznając Philiberta de Janly za najbardziej prawdopodobnego kandydata. Omówiono historyczne konteksty stojące za posiadaniem i przekazywaniem prezentów przez nobilitowanych dworzan burgundzkich, zwracając szczególną uwagę na rękopis I-Nn 40 z mszami L’homme armé podarowany królowej węgierskiej Beatrycze Aragońskiej, a także na jego historię po opuszczeniu Burgundii. Artykuł przedstawia również aktualny opis kodykologiczny księgi, umożliwiający nowe spojrzenie na jego powstanie i proces kopiowania.

\section{Przetożyt Pawet Gancarczyk}

Keywords / słowa kluczowe: L’homme armé, music manuscripts / rękopisy muzyczne, crusading / krucjaty, Burgundy / Burgundia, Beatrice of Aragon / Beatrycze Aragońska

Nicolò Ferrari studied musicology at the University of Pavia where he received an MA working on a critical edition of the settings of the Credo in the fifteenth-century manuscript Trent 93. He was recently awarded a $\mathrm{PhD}$ by the University of Huddersfield with a dissertation focussed on the Masses by Firminus Caron. In his research he focuses on philological issues as well as on cultural history. Currently he is working on a historiographical project which situates late medieval and Early Modern repertoire in the context of the late European crusading movement. 
